\title{
The Dietary Fiber Pectin: Health Benefits and Potential for the Treatment of Allergies by Modulation of Gut Microbiota
}

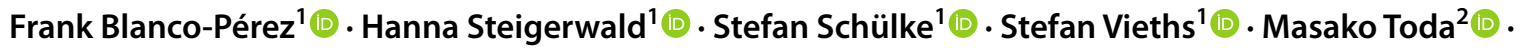 \\ Stephan Scheurer ${ }^{1}$ (i)
}

Accepted: 21 July 2021 / Published online: 10 September 2021

(c) The Author(s) 2021

\begin{abstract}
Purpose of Review The incidence of allergies is increasing and has been associated with several environmental factors including westernized diets. Changes in environment and nutrition can result in dysbiosis of the skin, gut, and lung microbiota altering the production of microbial metabolites, which may in turn generate epigenetic modifications. The present review addresses studies on pectin-mediated effects on allergies, including the immune modulating mechanisms by bacterial metabolites.

Recent Findings Recently, microbiota have gained attention as target for allergy intervention, especially with prebiotics, that are able to stimulate the growth and activity of certain microorganisms. Dietary fibers, which cannot be digested in the gastrointestinal tract, can alter the gut microbiota and lead to increased local and systemic concentrations of gut microbiotaderived short chain fatty acids (SCFAs). These can promote the generation of peripheral regulatory $\mathrm{T}$ cells $\left(\mathrm{T}_{\text {reg }}\right)$ by epigenetic modulation and suppress the inflammatory function of dendritic cells (DCs) by transcriptional modulation.

The dietary fiber pectin (a plant-derived polysaccharide commonly used as gelling agent and dietary supplement) can alter the ratio of Firmicutes to Bacteroidetes in gut and lung microbiota, increasing the concentrations of SCFAs in feces and sera, and reducing the development of airway inflammation by suppressing DC function.

Summary Pectin has shown immunomodulatory effects on allergies, although the underlying mechanisms still need to be elucidated. It has been suggested that the different types of pectin may exert direct and/or indirect immunomodulatory effects through different mechanisms. However, little is known about the relation of certain pectin structures to allergies.
\end{abstract}

Keywords Pectin $\cdot$ Dietary fiber $\cdot$ Prebiotics $\cdot$ Microbiota $\cdot$ SCFA $\cdot$ Allergy

\section{Introduction}

The manifestation of allergies frequently is associated with a dysbiosis of the gut microbiome, which can be affected by environmental factors, cesarean section, antiseptic agents, lack of breastfeeding, certain drugs, and a low-fiber/highfat diet $[1,2]$. In contrast, homeostasis of gut microbiota can be achieved by the intake of prebiotics [3, 4]. The

This article is part of the Topical Collection on Allergens

Frank Blanco-Pérez

frank.blanco@pei.de

1 Molecular Allergology, Federal Institute for Vaccines and Biomedicines, Paul-Ehrlich-Institut, Langen, Germany

2 Laboratory of Food and Biomolecular Science, Graduate School of Agricultural Science, Tohoku University, Sendai, Japan
International Scientific Association for Probiotics and Prebiotics (ISAPP) defined prebiotics as "a substrate that is selectively fermented by a host microorganism that allows specific changes, both in the composition and/or activity in the gastrointestinal microflora that confers benefits upon host well-being and health" [5-7]. To be classified as prebiotics, the compounds must meet the following criteria: (I) nondigestible and resistant to breakdown by stomach acid and enzymes in the human gastrointestinal tract, (II) selectively fermented by intestinal microorganisms of the host, and (III) selectively targeting and stimulating the growth and activity of beneficial bacteria in the gut $[8,9]$.

Prebiotics beneficially influence the health of the host by either (I) indirectly increasing the secretion of bacteriaderived metabolites into the intestinal tract, in turn influencing many molecular and cellular processes, or by (II) directly affecting the immune response of certain cells, e.g., 
epithelial and immune cells [10]. Therefore, prebiotics are considered as an immune active agent conferring a health benefit $[11,12]$.

Dietary fibers are polymers with three or more monomeric units (MU) which are mainly derived from edible parts of plants, certain types of animals (e.g., crustacean), or analogous carbohydrates that are neither digested nor absorbed in the human intestine [13]. Therefore, they pass through the upper part of the gastrointestinal tract into the large intestine where they are fermented by advantageous bacteria stimulating their growth and activity, which confer them prebiotic activity $[12,14,15]$. Dietary fibers consist of carbohydrates as non-digestible oligosaccharides (e.g., short-chain and long-chain fructooligosaccharides (sc/lc FOS) and galactooligosaccharides (GOS), inulin) [16]; non-starch polysaccharides such as pectin, chitins, beta-glucan; and other plant components such as cellulose [17-19], resistant starch [20], or resistant dextrin [21]. They also consist of non-carbohydrates, like lignin, that can also act as a dietary fiber (Fig. 1).

Dietary fibers confer health benefits comprising decreased risks of coronary heart disease, colon cancer, and type 2 diabetes. Clinically, fiber deficiency increases the risk of colon, liver, and breast cancer, and increases mortality and death from both cancerous and non-cancerous diseases [22].

Supplementation of prebiotics as food ingredients has been proposed to prevent several inflammatory diseases [23-27] as well as allergies [10, 28, 29, 30, 31, 32]. Cohort studies have indicated that one of the factors preceding the development of food allergies is gut dysbiosis [2, 33, 34]. Therefore, gut microbiota have gained attention as a target of intervention against allergies, especially with prebiotics.

So far, most studies exploring the effect of dietary fiber on the allergic immune response used non-digestible oligosaccharides [10, 35, 36]. Human milk-derived non-digestible oligosaccharides comprise short-chain galacto- (scGOS), long-chain fructo- (lsFOS), and acidic pectin-derived oligosaccharides (pAOS), which are together referred to as galacto-, fructo-, and acidic oligosaccharides (GFAs). Dietary fibers undergo microbial fermentation by commensal gut bacteria producing short-chain fatty acids (SCFA) with immune modulating properties [37, 38]. Long-term deficiency of dietary fiber intake increases the susceptibility to airway allergic disease (AAD), whereas proper fiber supplementation effectively promotes balanced Th1/Th2 immunity, significantly attenuates allergic inflammatory responses, and optimizes the structure of intestinal microbiota, which suggests its potential for novel preventive and therapeutic intervention strategies [39]. Taking this into consideration, this review gives an in-depth overview of the reported effects of dietary fiber pectin on the immunomodulation of allergic diseases.

\section{Pectin: Characteristics and Immune Modulating Effects}

\section{Pectin Structure}

Pectin is a dietary fiber accumulating in the primary cell walls and intercellular tissues of terrestrial plants, where it plays an important role as hydrating agent and cementing material [40, 41]. Pectin is a heterogeneous and complex acidic hetero-polysaccharide with a molecular mass of typically $50,000-150,000 \mathrm{~g} / \mathrm{mol}$, depending on extraction method and source material [42]. It contains a linear backbone of at least $65 \%$ galacturonic acid (GalA), which can either be free or methyl-esterified at the carboxyl groups present at C-6 (Fig. 2) [43, 44]. The pectin macromolecule contains fragments of linear and branched regions of polysaccharides such as homogalacturonan, rhamnogalacturonan, xylogalacturonan, and apiogalacturonan $[45$,
Fig. 1 Dietary fibers (overview). Dietary fibers are polymers mainly derived from edible parts of plants, certain types of animals or analogous carbohydrates that are neither digested nor absorbed in the human intestine. They can be divided into carbohydrates and non-carbohydrates (e.g., lignin). Carbohydrate fibers can be further subdivided in non-digestible oligosaccharides or polysaccharides such as non-starch-, resistant starch-, or dextran polysaccharides

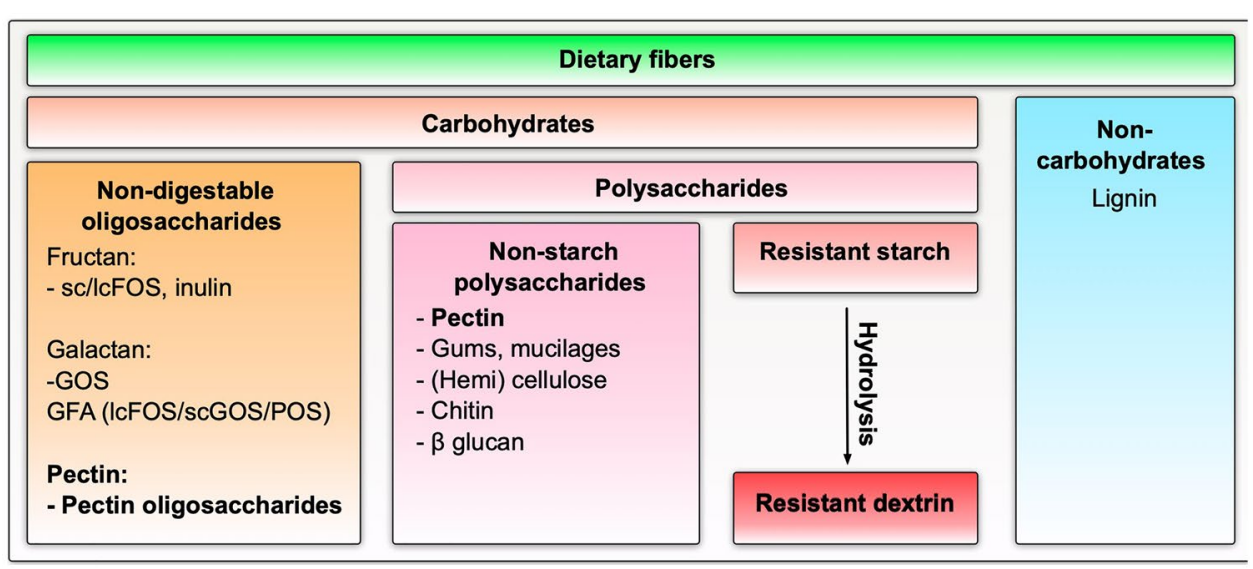


46]. In native, non-processed pectin, approximately $80 \%$ of carboxyl groups of GalA are esterified with methanol and present as methyl esters. Thus, the ratio of esterified GalA groups to total GalA groups is termed the degree of esterification (DE). Pectins are classified as high methoxy pectin (HMP) with DE $>50 \%$ or low methoxy pectin (LMP) with $\mathrm{DE}<50 \%$ (Fig. 2) [44]. The majority of natural pectins is HMP ( 80\% DE), whereas LMP is more common in processed foods $[47,48]$. The degree of esterification determines the properties of pectin in food technology as HMP can form a gel under acidic conditions $(\mathrm{pH} \sim 3)$ in the presence of high sugar concentrations, while LMP form gels by interaction with divalent cations, particularly $\mathrm{Ca}^{2+}[47$, 48]. Both HMP and LMP appear to possess immunomodulatory effects in mice. LMP likely is more efficiently fermented by the microbiota in the ileum, whereas HMP is mainly fermented in the proximal colon [49]. Moreover, it is suggested that structural features determine the effect of pectin on the immune system. Evidence has been provided that the backbones of pectin macromolecules have immunosuppressive activity [50].

Depolymerization of purified pectin or the raw materials by partial enzymatic hydrolysis leads to production of Pectin-derived oligosaccharides (POS) which were indicated as new prebiotic candidates [51]. The main suggested properties of POS stimulation are (I) growth of beneficial bacteria in the colon, (II) apoptosis of colon cancer cells, and (III) protection again various pathogens [51]. The different POS can include galacturonic acid (GalA), rhamnose (Rha), arabinose (Ara), and galactose (Gal) [52]. GFAs, consisting of pAOS, have shown to lower immune responses in cow-milk-allergic (CMA) mice, to enhance regulatory $\mathrm{T}$ cell $\left(\mathrm{T}_{\text {reg }}\right)$ frequencies, and to induce mucosal IL-10 and TGF- $\beta$ transcription while suppressing the allergic effector response [53]. Both animal studies and human clinical trials showed that dietary intervention with these dietary oligosaccharides early in life could lead to the prevention of atopic dermatitis, food allergy, and allergic asthma [10, 37, 54, 55]. In line with this, supplementation with two mixtures of scGOS/ lcFOS or scGOS/lcFOS/pAOS decreased the OVA-induced airway inflammation and hyperresponsiveness in mice [56]. Moreover, OVA-specific IgE titers were decreased by more than $25 \%$, although this effect was not significant [56]. The effects of the oligosaccharide mixture containing pAOS appeared to be more pronounced than the effects of the scGOS/lcFOS mixture without pAOS [56].

\section{Pectin-Mediated Health-Promoting Effects}

Pectin and dietary fibers in general are considered to provide diverse health benefits including slow gastric emptying [57], improvement of physical bowel function [58], reduced glucose and cholesterol absorption [59], and increase of fecal mass $[60,61]$. Pectin is recognized as a prebiotic that is not degraded by either human saliva or gastric acid and is resistant to pepsin, trypsin, and rennet [62, 63]. Several studies demonstrated that pectins from different sources such as apple [64] or citrus [65] can serve as valuable carbon sources for gut bacteria [66•]. The ability to degrade pectins seems to be a common trait among Gram-negative Bacteroides species in the human colon [67], whereas only few Gram-positive bacterial species like Firmicutes seem to ferment either pectin or its breakdown products [68]. Pectin is fermented by beneficial microbiota mainly in the large intestine (colon), generating the SCFAs acetate, propionate, and butyrate, all of which have beneficial health effects $[69$, 70]. Evidence suggests that SCFAs can affect the epigenome through metabolic regulatory receptors, potentially reducing obesity, diabetes, atherosclerosis, mucosal inflammation, carcinogenesis, and allergy [22, 71, 72, 73, 74].

The average daily intake of pectin from fruit and vegetables has been estimated to be around $5 \mathrm{~g}$, considering a fruit and vegetable consumption of $500 \mathrm{~g}$ per day [75]. Several studies reported that high-fiber diets improve diabetic control via
Fig. 2 Pectin structure and health benefits. Pectin consists of a linear backbone of at least $65 \%$ galacturonic acid (GalA) that can be methyl-esterified at the carboxyl groups present at C-6. The ratio of esterified to non-esterified GalA groups is termed the degree of esterification (DE). Pectin are classified as high methoxy pectin (HMP) with DE $>50 \%$ or low methoxy pectin (LMP) with $\mathrm{DE}<50 \%$

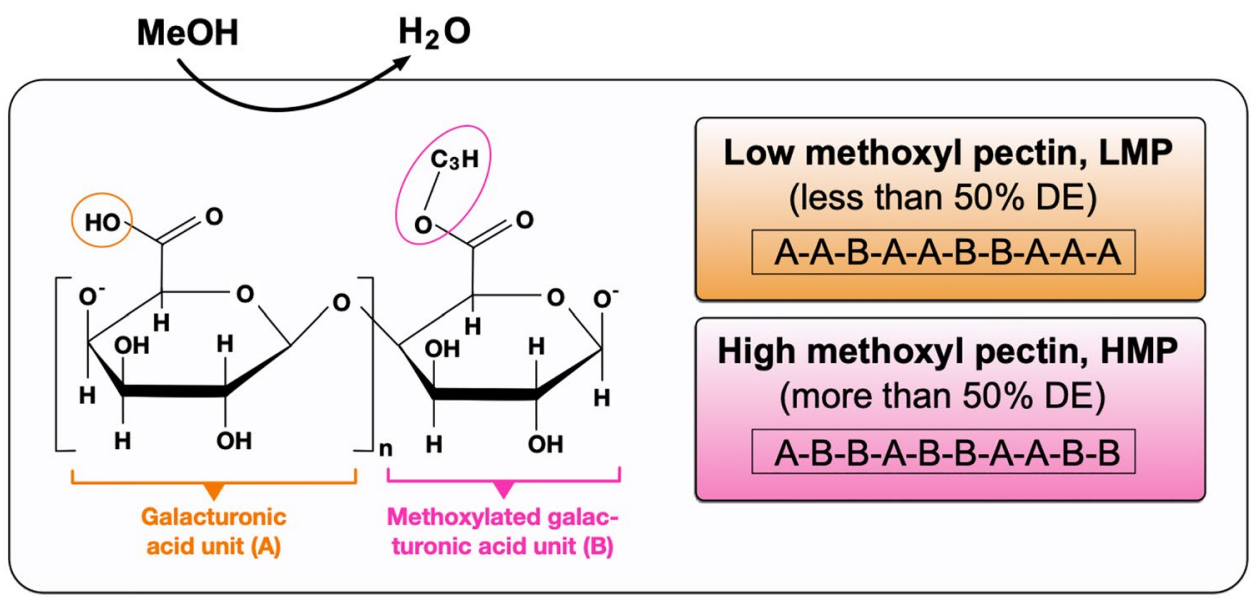


decrease of both glucose and cholesterol absorption as well as lowered serum triglyceride levels [76, 77]. It was found that several dietary fibers lead to delayed absorption of glucose and fatty acids from the upper small intestine, decreasing available substrates for triglyceride synthesis [78]. In humans, pectin consumption ( $15 \mathrm{~g} /$ day over a period of 4 weeks) has been shown to slightly reduce blood LDL cholesterol levels by $3-7 \%[79,80]$. This effect likely depends on the source of pectin, since apple and citrus pectin were found to be more effective than orange pulp fiber pectin [79]. However, the mechanism appears to be related to an increase of viscosity in the intestinal tract, leading to a reduced absorption of cholesterol from either bile or food [75, 81]. Studies propose that the SCFA propionate leads to activation of the adenosine monophosphate-activated protein kinase (AMPK), which is one of the regulators for glucose metabolism in the liver [65, 82-84]. Activated AMPK inhibits acetyl-CoA carboxylase (ACC) leading to a decrease of lipogenesis [65]. Other studies in Apo E-deficient mice comparing high-cholesterol diet (HCD) with or without pectin supplementation showed improved lipid profiles and reduced atherosclerotic plaques in the HCD/pectin group [81]. The study suggested that microbiota-dependent butyrate production inhibits intestinal cholesterol absorption, leading to decreased levels of atherosclerosis [85].

Furthermore, pectin has favorable effects on maintaining the intestinal barrier, which consists of a thick mucus layer protecting the intestinal epithelial tissue. Recent studies found that intervention with pectin in mice led to increased amount of colonic gel-forming mucin 2 (MUC2), the expression of which is related to both the thickness of mucus layer and gut health [86].

Supplementation with LMP reduced type 1 diabetes (T1D) incidence in non-obese diabetic (NOD) mice by positively impacting cecal microbiota, enhancing the production of immune modulating bacterial SCFAs, as well as improving intestinal integrity in the cecum [87]. The maintenance of gut homeostasis by LMP further results in modulated gut-pancreatic autoimmune responses and in protection against T1D development [87]. Other studies revealed that pectin supplementation improved insulin and glucose profiles and reverse calorie restriction (CR)-induced insulin resistance in the rat CR model [88]. By suppressing pro-inflammatory cytokine production, LMP was shown to have anti-inflammatory effects [89]. A fiber-rich diet was also shown to improve glycemic control in patients with type 2 diabetes mellitus [90].

It is suggested that pectin binds metals in the digestive tract, preventing their absorption [91]. Consequently, orally administered pectin is known to (I) remove heavy metals, (II) decrease lead absorption, and (III) reduce strontium bone and blood levels [92, 93].

Furthermore, pectin shows beneficial anti-cancer effects. Studies revealed that $\mathrm{pH}$-modified citrus pectins (MCP), rich in galactoside residues, significantly diminish the number of lung metastases in C57BL/6 mice [94, 95]. This suggests that the galactoside residues impair cell-cell interactions by competing with the endogenous ligands of galactosidebinding proteins such as galectin-3 [94, 95]. Further studies found that modified apple pectin induces apoptosis in colorectal cancer cells by a dose-dependent increase of caspase $3,-8$, and -9 expression [96].

A further health claim associated with pectin affects Alzheimer's disease. A recent study suggests an impact of pectin polysaccharide on $\mathrm{A} \beta_{42}$, an important molecule for pathology of Alzheimer's disease, by inhibition of its aggregation [97].

Moreover, it has been suggested that pectin has beneficial effects on the manifestations of IgE-mediated food and respiratory allergy $[98 \bullet \bullet]$.

\section{Effect of Pectin on the Immune Response and Allergic Sensitization}

Pectin displays diverse immunomodulatory properties, comprising both direct effects on immune cells and indirect effects mediated by bacterial metabolites upon fermentation of pectin in the gut (Fig. 3) [99, 100•].

Dietary fibers can directly interact with intestinal cells and mucosal immune cells [101], affecting immune cell responses by interaction with pattern recognition receptors (PRRs). Thereby distinct binding capacities of different pectins may cause the reported differences in immunomodulatory efficiency [102, 103]. The best characterized PRRs in the intestine are Toll-like receptors (TLRs), which were shown to also recognize dietary fibers [104, 105]. It was elucidated in human DCs and the mouse macrophage cell line RAW264.7 in vitro that pectin binds the ectodomain of Toll-like receptor 2 (TLR2) by electrostatic interactions and specifically inhibits the pro-inflammatory TLR2-TLR1 pathway while the tolerogenic TLR2-TLR6 pathway remains unaffected (Fig. 3) [105]. This effect was predominantly achieved with pectin having a low DE [105].

The immunomodulatory effects of pectin mainly depend on the content of galacturonic acid residues and the DE. Pectin with DE up to 80-90\% inhibited iNOS and COX2 expression in murine peritoneal macrophages and inhibited MAPK phosphorylation, IKK kinase activity, and NF- $\mathrm{KB}$ activation more efficiently than pectin with lower DE (Fig. 3) [106]. In this context, highly esterified pectin was able to bind LPS, modifying its binding to TLR4 $[50,106]$. Additionally, MCP with a decreased molecular weight and DE was shown to activate cytotoxic T cells, B cells, as well as NK cells in a dose-dependent manner [107]. Comparing the immunomodulatory effects of native and modified pectin on the example of citrus pectin showed, both types of pectin led to upregulated levels of IFN- $\gamma$ in the spleen [108]. MCP, but also native citrus pectin, led to increased levels of TNF-a-, 


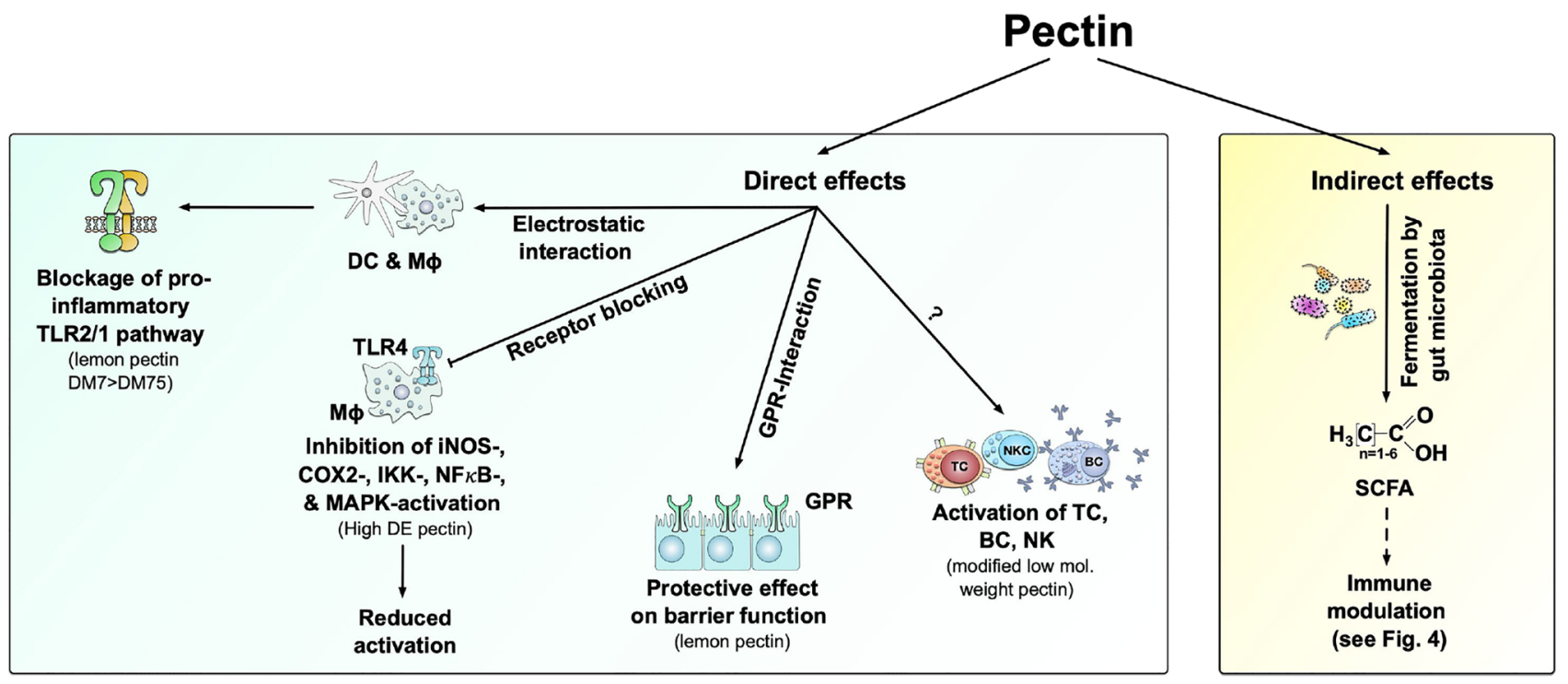

Fig. 3 Immune modulation by pectin. Immune modulation by dietary fibers can either be indirectly mediated by their fermentation into short chain fatty acids (SCFAs) or directly caused by the pectin, e.g., via the blockage of the pro-inflammatory TLR2/1 pathway. Sev-

IFN- $\gamma-$, and IL-17 secretion, likely regulated by IL-4 [108]. Unbranched galacturonan regions were shown to increase the anti-inflammatory properties of pectin [109].

The role of pectin in the manifestation of type 1 allergies is controversially discussed. Different pectins are described to either promote or prevent allergies [98••, 110-114]. The matrix effect of pectin-rich fruits has been suggested to reduce the digestibility of food allergens and thereby to facilitate the process of allergic sensitization in atopic individuals [115]. In line with this, the addition of apple pectin to purified kiwi allergen was able to protect the allergen from pepsin digestion in vitro [115]. An independent study showed that pectin reduces the accessibility of cleavage sites and/or epitope sequences of $\beta$-lactoglobulin through a non-specific interaction [116]. Other studies also reported anaphylaxis induced by pectin (Table 1) [110, 111, 113]. Pectin-mediated allergy was reported after drinking a pectin-containing smoothie [110]. In line with this, a positive skin prick test to both pectin and cashew was reported, and cross-reactivity between pectin and cashew was considered [110, 114]. Reports from the 1990s found that continued airborne exposure to pectin in the workplace was associated with the development of occupational asthma [117-119]. Jaakkola et al. reported 3 patients that developed occupational asthma after frequent inhalation of pectin [119]. Two patients showed immediate reduction in lung functions after an inhalation challenge with pectin and positive SPT, while the third showed a late response ( $10 \mathrm{~h}$ after the challenge) and dermographism after the SPT. Of the 3 patients only one had a positive RAST to pectin [119]. eral positive health effects are associated with consumption of pectin such as maintaining the intestinal barrier, immune modulation like the activation of immune cells ( $\mathrm{T}, \mathrm{B}, \mathrm{NK}$ cells), and the inhibition of inflammatory responses

In vivo, oral administration of citrus pectin prevented the induction of immune tolerance induced by feeding of a high dose of OVA [120]. Citrus pectin feeding inhibited the development of the oral tolerance in the OVA-treated mice. Mice fed with pectin showed similar titers of antigen-specific serum IgG and similar levels of delayed-type hypersensitivity responses as those animals not tolerant. Here, citrus pectin increased the levels of serum OVA-specific IgG1 and IgE [120].

In contrast, other studies reported a beneficial effect of pectin on allergic sensitization by alteration of the intestinal microbiota [39]. Increased numbers of beneficial bacteria like Bifidobacterium and the higher production rate of bacteria-derived SCFAs were suggested to lower the risk of food allergies [121]. Pectin containing more than $80 \%$ galacturonic acid residues was found both to decrease macrophage activity and inhibit delayed-type hypersensitivity reactions [50]. Moreover, alkali-soluble pectin suppressed IgE production in a human myeloma cell line in vitro [112]. Other results also indicate that administration of Asian pear pectin-sol (a pH and enzymatically modified pectin in colloidal dispersion) in sensitized mice suppressed allergic asthmatic reactions [122]. However, little is known whether pectin from different plant sources and different degrees of esterification exert distinct immune modulating properties.

\section{Modulation of Gastrointestinal Microbiota by Pectin}

Pectin and POS are fermented in the colon by different bacterial genera such as Bifidobacteria, Lactobacilli, Enterococcus, Eubacterium rectale, Faecalibacterium prausnitzii, 


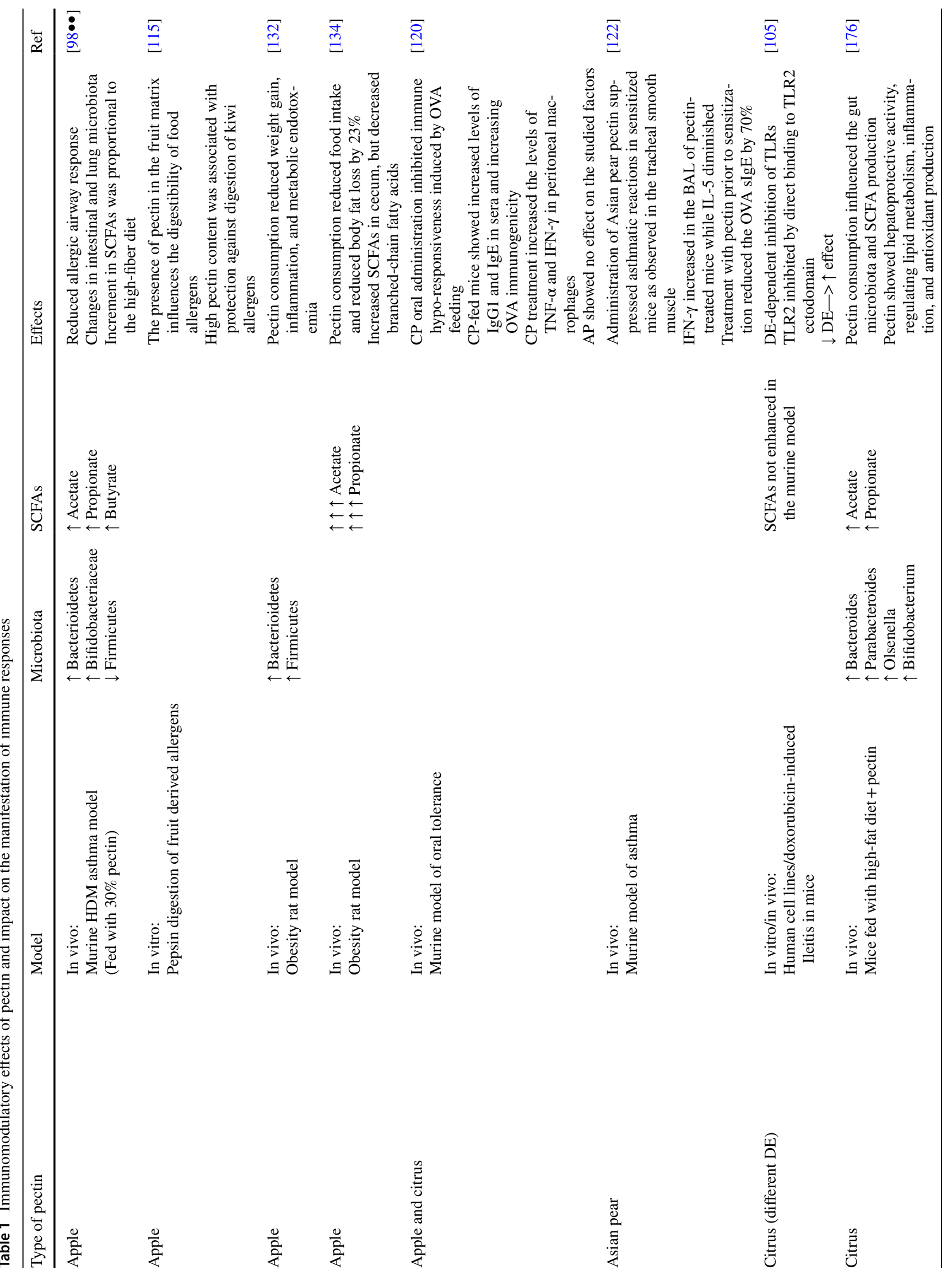




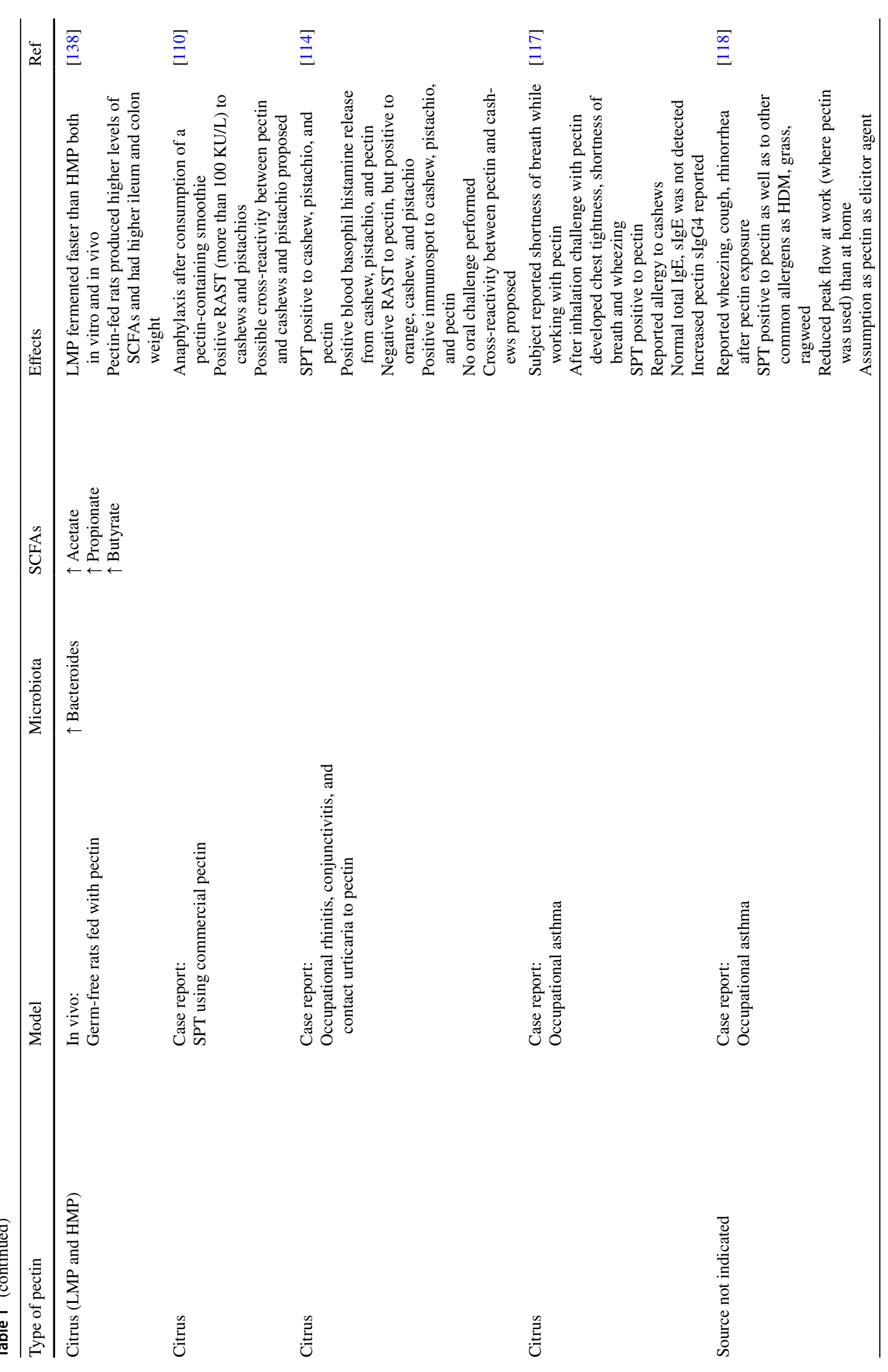




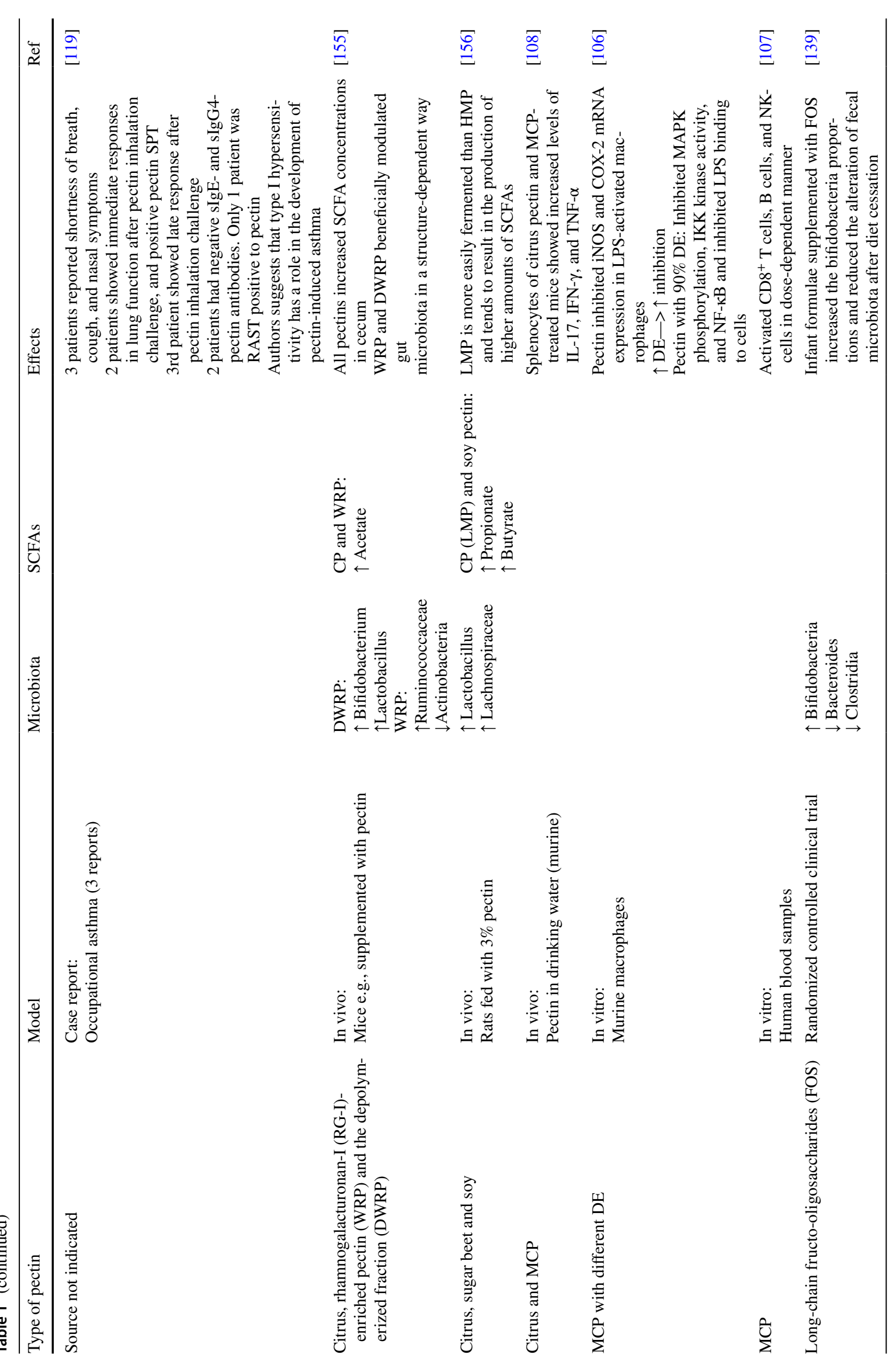




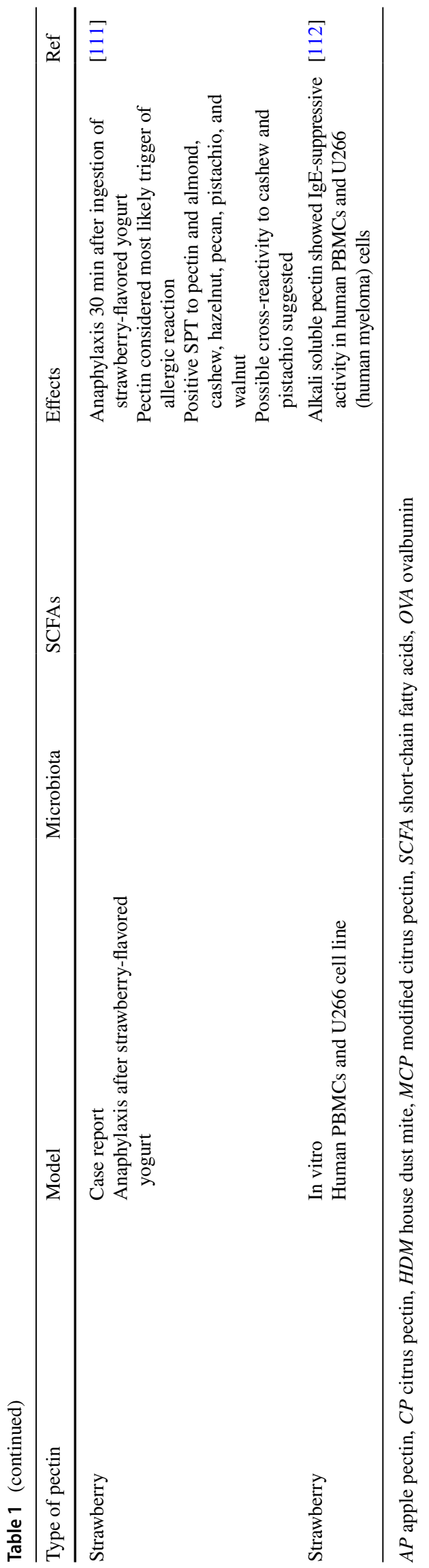

Clostridium, Anaerostipes, and Roseburia spp. in order to promote their growth $[68,69,123,124]$. The degradation of pectin is facilitated by different bacteria-derived enzymes such as pectinases, methylesterases, acetylsterases, and lyases [125-127], generating different POS that will vary depending on microbiota composition and pectin structure $[69,100 \bullet, 128-132]$.

As mentioned before, the biological properties of both pectin and POS depend on different features such as molecular weight (MW) and type and structure of constituents (e.g., galacturonic acid or rhamnose) and DE [51, 128]. It is reported that pectin from orange, lemon, and sugar beet with high degree of methylation increase the colonization by Bifdobacterium, Bacteroides, and Eubacterium species, while the POS derived from the same sources promoted the presence of Bifidobacterium species, Bacteroides, and Lactobacillus when compared to the primary pectin [133••]. Pectins with high DE are degraded slower than the ones with lower $\mathrm{DE}$ and are reported to remain in the intestine for up to $24 \mathrm{~h}$ [134-136], while pectins with lower DE were easily metabolized [135-138]. In vitro fermentation studies of pectin and POS using human fecal samples have shown an increase in the number of Bifidobacteria, Eubacterium rectale, Clostridium coccoides, and Bacteroides prevotella, with an elevated production of acetate, propionate and butyrate (summarized in Table 2) $[40,129]$. The shift observed in the microbiota correlates with clinical effects of POS: POS-supplemented infant formulae was shown to both increase the number of Bifidobacteria and Lactobacilli and minimize the alteration of fecal microbiota after cessation of breast-feeding [139].

It is well accepted that an increase in bacteria-derived SCFAs promotes a protective effect in the intestine [74, 140-142]. In line with this, the composition of the gut microbiota can influence the development of the immune system and homeostatic processes at which the dysbiosis of microbial composition can increase the susceptibility for immune-mediated diseases, like asthma or allergy (reviewed in [143•]).

Compared to LMP, the fermentation of HMP increased the abundance of Prevotella and Ruminococcus species and was paralleled by higher levels of the SCFA propionate [100•, 144]. Particularly, levels of Ruminococcus-derived propionate are enhanced when stimulated with rhamnose and fucose, both of which are structural subunits of pectin. This indicates that a higher production of propionate could relate with a high pectin content of rhamnose and fucose, as well as its slower fermentation process [145-147]. The SCFA acetate is reported to be produced by many different genera, but mainly by Bifidobacteria and Lactobacilli (Table 2) [148, 149]. Propionate is mainly produced by Bacteroidetes and Firmicutes (via the succinate pathway) [146, 150], while butyrate is produced by Eubacterium rectale, Roseburia intestinalis, Faecalibacterium prausnitzii, and 


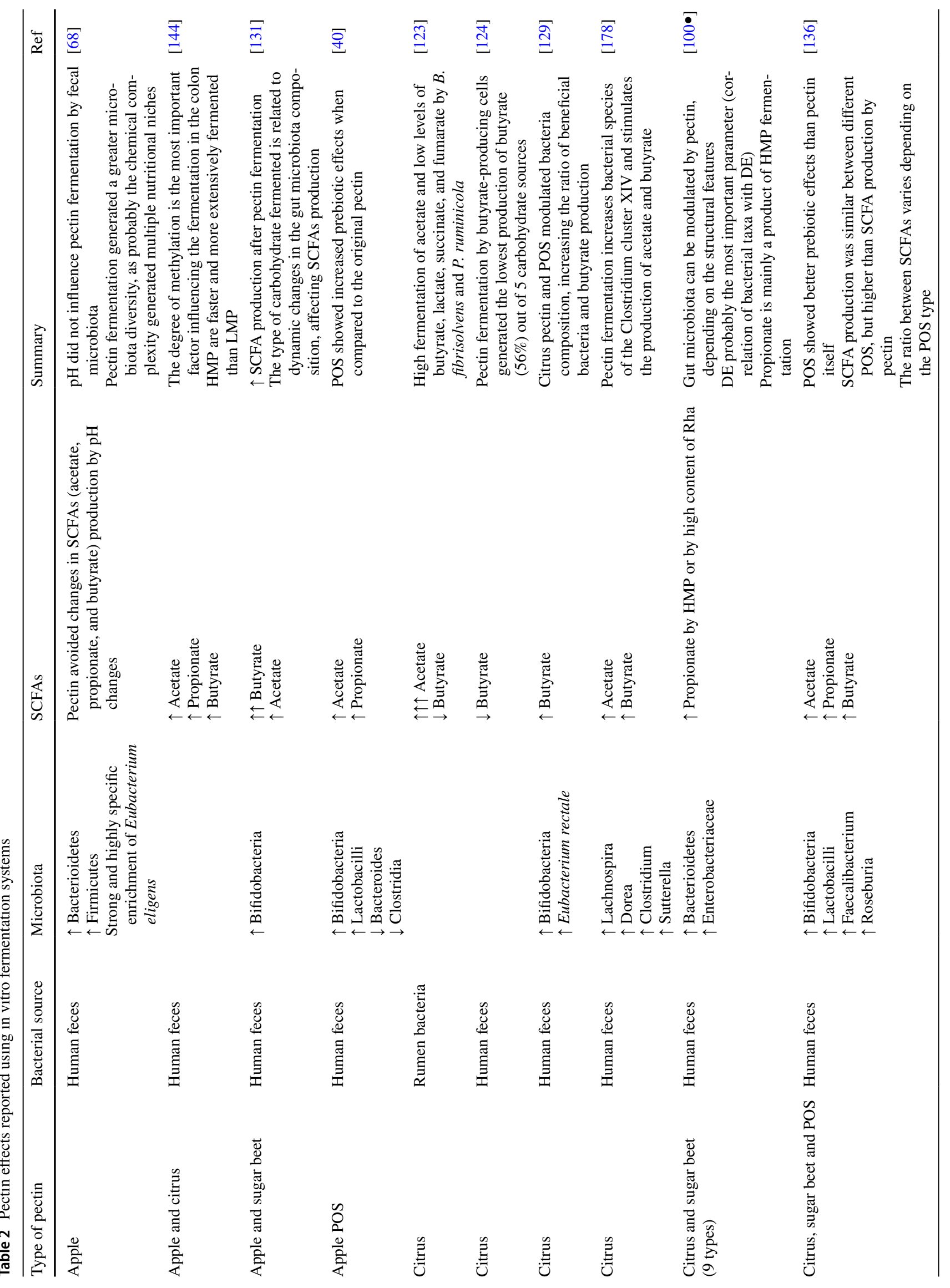


some Clostridia species (both from pyruvate via butyryl CoA:acetate CoA transferase and directly from acetate (Fig. 4) [151, 152].

\section{Pectin-Induced Short-Chain Fatty Acids}

Dietary fibers, including pectin, are fermented by commensal gut bacteria, which produce metabolites including SCFAs, particularly butyrate, propionate, acetate, and pentanoate (valerate) [36, 74, 100•, 138, 144, 153, 154]. Fermentation of every structurally distinct pectin induces specific profiles of SCFAs in the gastrointestinal tract $[100 \bullet, 103,138,144$, $155,156]$. In addition, the generation of SCFAs is strongly dependent on substrate availability, microbiota composition, and intestinal transit time [157].

SCFAs can mediate anti-inflammatory effects by (I) enhancing the frequency of immune regulatory $\mathrm{T}_{\text {reg }}$ cells in the intestine [158], (II) inhibiting Th2-mediated airway diseases in mice [159], (III) stimulating epithelial cell growth, (IV) suppressing APC activation, and (V) maintaining a low $\mathrm{pH}$ in the intestine (which inhibits pathogen growth) [103, 157]. Vice versa, a dysfunctional microbiome with a reduced capacity to produce SCFAs is prone to the development of allergic diseases [160]. SCFAs likely modulate immune responses by three different mechanisms: (I) directly activating G-coupled receptors, (II) inducing epigenetic modifications by inhibiting histone deacethylases (HDAC), and (III) serving as energy substrates for both immune and nonimmune cells (Fig. 4) [121, 161•].

The molecular mechanisms by which SCFAs are involved in the "diet-gut microbiota-physiology axis" have been explored recently. SCFAs bind "metabolite-sensing" G-protein-coupled receptors such as GPR41 (affinities: acetate $=$ propionate $>$ butyrate), GPR 43 (butyrate $=$ propion ate $>$ acetate), GPR109A (butyrate), and olfactory receptor $(\mathrm{Olfr})-78$ (propionate $=$ acetate) $($ reviewed in [10]). These receptors play fundamental roles in the promotion of gut homeostasis and the regulation of inflammatory responses (Fig. 4). For instance, GPRs and their metabolites influence $\mathrm{T}_{\text {reg }}$ activation, epithelial integrity, gut homeostasis, DC biology, and IgA antibody responses $[6,162]$. Through the inhibition of HDAC expression or function, SCFAs also influence gene transcription in many cells and tissues [163]. GPR41 and GPR43 are expressed on epithelial cells, macrophages, and DCs [6]. Here, GPR43 is engaged in suppression of bacterial invasion into the tissue, prevention of inflammation, intestinal carcinogenesis (reviewed in [164]), and allergy [165]. GPR109A is expressed primarily in adipocytes and immune cells as DCs, neutrophils, macrophages, intestinal and colonic epithelial cells [166-169]. The GPR109A/butyrate axis is reported to suppress the tumor development and progression and the LPS-induced NF-KB activation [170], as well as 


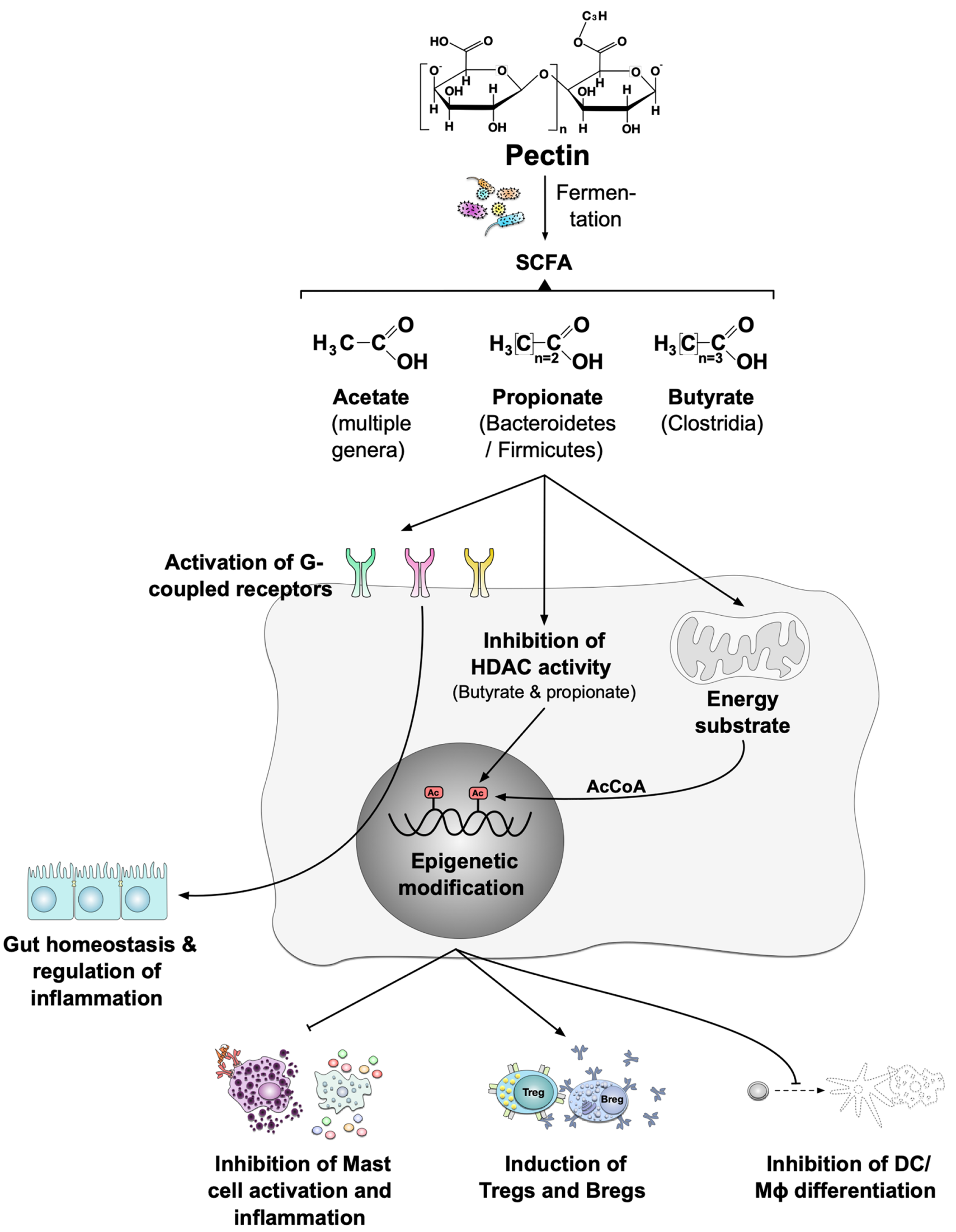


४Fig. 4 Immune modulation by pectin-derived SCFAs. Pectin fermentation by gut microbiota leads to the production of SCFAs. Different genera can generate different SCFAs. For example, acetate can be produced by many different genera; propionate is mainly produced by Bacteroidetes and Firmicutes, while butyrate is mainly produced by Clostridia species. SCFA bind "metabolite-sensing" G-proteincoupled receptors such as GPR41, GPR43, GPR109A, and olfactory receptor (Olfr)-78. These receptors promote the gut homeostasis and the regulation of inflammatory responses. GPRs and their metabolites influence $\mathrm{T}_{\text {reg }}$ activation, epithelial integrity, gut homeostasis, DC biology, and IgA antibody responses. Through their inhibition of HDAC expression or function, SCFAs also influence gene transcription in many cells and tissues

an anti-inflammatory role by modulation factors like CCL5, MCP-1, and TNF- $\alpha$ [171-174].

High levels of both butyrate and propionate in early life are associated with protection against atopy [175••]. Trompette et al. reported that feeding mice with either a high pectin diet or supplementation of propionate enhance levels of SCFAs and protected against allergic lung inflammation [98••]. These protective effects were shown to be independent of either $\mathrm{T}_{\text {reg }}$ induction, activation status, or recruitment of dendritic cells to draining lymph nodes [98••]. In their model, propionate treatment enhanced hematopoiesis of common DC precursors and macrophage-DC precursors [98••].

In line with these anti-inflammatory properties of pectin, oral ingestion of pectin for 8 weeks in a mouse model of non-alcoholic fatty liver disease MAPK dependently improved lipid metabolism and decreased both oxidative stress and inflammation [176]. In this study, pectin feeding dose-dependently increased levels of both acetic and propionic acids and relative abundance of Bacteroides, Parabacteroides, Olsenella, and Bifidobacterium species in the gut of pectin-fed mice [176].

In rats, Fukunaga et al. reported pectin supplementation (2.5\% pectin for 15 days) to result in significant increases in the length, weight, and number of Ki-67-positive cells in the ileum, cecum, and colon [177]. While in this model, pectin supplementation did not affect the composition of the cecal microbial flora, cecal SCFA content and plasma glucagon-like peptide- 2 in small intestine were significantly increased [177].

Larsen et al. characterized the relationship between structural properties of pectin and their ability to modulate both composition and activity of gut microbiome [100•]. In vitro fermentation of nine structurally diverse pectins from citrus fruits, sugar beet, and a pectin derivative rhamnogalacturonan I using a TIM-2 colon model under anaerobic conditions was performed [100•]. Here, cumulative production of total SCFAs as well as propionate was highest for fermentation of high methoxyl pectin (including rhamnogalacturonan I), while acetate levels were similar for all investigated pectins [100•]. This increased production of SCFAs by RG-I was independently confirmed in rats fed with RG-I-enriched diets
[155]. Interestingly, bacterial populations associated with human health (e.g., F. prausnitzii, Coprococcus, Ruminococcus, Dorea, Blautia, Oscillospira, Sutterella, Bifidobacterium, Christensenellaceae, P. copri, and Bacteroides spp.) were either increased or decreased depending on the used pectin, suggesting that microbial communities in the gut can be specifically modulated using different pectins [100•].

Finally, Bang and co-authors performed in vitro fermentation ( $1 \%$ pectin from citrus peel) experiments using the feces of three Korean donors in order to investigate pectin-induced changes in the gut microbiome and SCFA production [178]. Pectin fermentation commonly increased the frequencies of pectin-degrading bacterial species belonging to the Clostridium cluster XIV (Lachnospira, Dorea, and Clostridium) and Lachnospira paralleled by an increase in acetate (starting as early as $6 \mathrm{~h}$ after start of incubation), as well as propionate and butyrate (after $12 \mathrm{~h}$ of incubation) [178].

\section{Summary}

The role of dietary fiber pectin in the development of allergic reactions is controversial. Several clinical reports indicate the manifestation of allergic reactions after pectin consumption, probably attributed to cross-reactivity between pectin and allergens. Moreover, pectin was also described to prevent the digestion of allergens in the stomach, facilitating intact allergen molecules to reach the gut and to induce allergic reactions.

However, others showed direct and indirect immune modulating effects of pectin. A broad set of evidence describing application of pectin to induce a shift to beneficial microbiota and an increase in the levels of SCFAs, both of which have been associated with reduced inflammatory and allergic reactions in vitro and in vivo has been provided. As bacterial populations associated with human health were either increased or decreased by different pectins, it is likely that bacterial communities in the gut can be specifically modulated by pectin application. Pectin is able to directly interact with immune cells such as DCs and macrophages by electrostatic interactions with TLR2, thereby inhibiting the pro-inflammatory TLR2-TLR1 pathway, while not affecting the TLR2-TLR6 tolerogenic pathway. Also, it is able to bind LPS affecting its binding to TLR4. Other cell types such as T cells, B cells, and NK cells are also activated by pectin, while iNOS and COX-2 expression are inhibited in peritoneal macrophages by inhibition of the IKK activity, MAPK phosphorylation, and NF- $\kappa \mathrm{B}$ activation, suggesting an anti-inflammatory property.

Considering the data reviewed here, it is tempting to speculate that dietary fiber including certain pectin can be considered for prophylactic intervention targeting microbiota in immune-related diseases, such as allergies. The immune 
modulating effect seems to be dependent on the structure and source of the pectin. In particular, the direct immune modulating mechanism by pectin and pectin-derived products generated by food processing and fermentation remain to be investigated.

Abbreviations Ara: Arabinose; DE: Degree of esterification; FA: Food allergy; FOS: Fructooligosaccharide; Gal: Galactose; GalA: Galacturonic acid; GFA: Fructo- and acidic-oligosaccharide; GOS: Galactooligosaccharide; GPR: G-protein-coupled receptor; HDAC: Histone deacetylase; HMP: High methoxy pectin; LMP: Low methoxy pectin; MCP: Modified citrus pectin; OVA: Ovalbumin; pAOS: Pectin-derived acidic oligosaccharides; POS: Pectic polysaccharides; Rha: Rhamnose; SCFAs: Short-chain fatty acids

Author Contribution Schst and MT conceived the topic and structure of this review. FBP, Schü, HS, MT, SV and Schst wrote the review.

Funding Open Access funding enabled and organized by Projekt DEAL. FBP was funded by the BMWi, German Federal Ministry for Economic Affairs and Energy, AIF20528. HS was funded by BMBF, German Federal Ministry for Education and Research, 01EA1901.

\section{Declarations}

Human and Animal Rights and Informed Consent This article does not contain any studies with human or animal subjects performed by any of the authors.

Conflict of Interest The authors have no conflicts of interest to declare.

Open Access This article is licensed under a Creative Commons Attribution 4.0 International License, which permits use, sharing, adaptation, distribution and reproduction in any medium or format, as long as you give appropriate credit to the original author(s) and the source, provide a link to the Creative Commons licence, and indicate if changes were made. The images or other third party material in this article are included in the article's Creative Commons licence, unless indicated otherwise in a credit line to the material. If material is not included in the article's Creative Commons licence and your intended use is not permitted by statutory regulation or exceeds the permitted use, you will need to obtain permission directly from the copyright holder. To view a copy of this licence, visit http://creativecommons.org/licenses/by/4.0/.

\section{References}

Papers of particular interest, published recently, have been highlighted as:

- Of importance

$\bullet$ Of major importance

1. Berni Canani R, Paparo L, Nocerino R, Di Scala C, Della Gatta $\mathrm{G}$, Maddalena $\mathrm{Y}$, et al. Gut microbiome as target for innovative strategies against food allergy. Front Immunol. 2019;10:191. https://doi.org/10.3389/fimmu.2019.00191.

2. Lee KH, Song $\mathrm{Y}, \mathrm{Wu} \mathrm{W}$, et al. The gut microbiota, environmental factors, and links to the development of food allergy. Clinical and molecular allergy : CMA. 2020;18:5. https://doi.org/10.1186/ s12948-020-00120-x.

3. Hasan N, Yang H. Factors affecting the composition of the gut microbiota, and its modulation. PeerJ. 2019;7: e7502. https:// doi.org/10.7717/peerj.7502.

4. Cani PD, van Hul M, Lefort C, Depommier C, Rastelli M, Everard A. Microbial regulation of organismal energy homeostasis. Nat Metab. 2019;1:34-46. https://doi.org/10.1038/s42255-018-0017-4.

5. Sun Y, O'Riordan MXD. Regulation of bacterial pathogenesis by intestinal short-chain Fatty acids. Adv Appl Microbiol. 2013;85:93-118. https://doi.org/10.1016/B978-0-12-407672-3.00003-4.

6. Sun M, Wu W, Liu Z, et al. Microbiota metabolite short chain fatty acids, GPCR, and inflammatory bowel diseases. J Gastroenterol. 2017;52:1-8. https://doi.org/10.1007/s00535-016-1242-9.

7. Gibson GR, Scott KP, Rastall RA, Tuohy KM, Hotchkiss A, Dubert-Ferrandon A, et al. Dietary prebiotics: current status and new definition. Food Science \& Technology Bulletin: Functional Foods. 2010;7:1-19. https://doi.org/10.1616/1476-2137.15880.

8. Gibson GR, Hutkins R, Sanders ME, Prescott SL, Reimer RA, Salminen SJ, et al. Expert consensus document: the International Scientific Association for Probiotics and Prebiotics (ISAPP) consensus statement on the definition and scope of prebiotics. Nat Rev Gastroenterol Hepatol. 2017;14:491-502. https://doi.org/ 10.1038/nrgastro.2017.75.

9. Slavin J. Fiber and prebiotics: mechanisms and health benefits. Nutrients. 2013;5:1417-35. https://doi.org/10.3390/nu5041417.

10. Brosseau C, Selle A, Palmer DJ, Prescott SL, Barbarot S, Bodinier M. Prebiotics: mechanisms and preventive effects in Allergy. Nutrients. 2019. https://doi.org/10.3390/nu11081841.

11. Miqdady M, Al Mistarihi J, Azaz A, et al. Prebiotics in the infant microbiome: the past, present, and future. Pediatr Gastroenterol Hepatol Nutr. 2020;23:1-14. https://doi.org/10.5223/pghn.2020. 23.1.1.

12. Shah BR, Li B, Al Sabbah H, et al. Effects of prebiotic dietary fibers and probiotics on human health: With special focus on recent advancement in their encapsulated formulations. Trends Food Sci Technol. 2020;102:178-92. https://doi.org/10.1016/j. tifs.2020.06.010.

13. Scientific Opinion on Dietary Reference Values for carbohydrates and dietary fibre. EFSA Journal 2010. https://doi.org/10. 2903/j.efsa.2010.1462.

14. Hutkins RW, Krumbeck JA, Bindels LB, Cani PD, Fahey G, Goh YJ, et al. Prebiotics: why definitions matter. Curr Opin Biotechnol. 2016;37:1-7. https://doi.org/10.1016/j.copbio.2015.09.001.

15. Holscher HD. Dietary fiber and prebiotics and the gastrointestinal microbiota. Gut Microbes. 2017;8:172-84. https://doi.org/ 10.1080/19490976.2017.1290756.

16. Lamsal BP. Production, health aspects and potential food uses of dairy prebiotic galactooligosaccharides. J Sci Food Agric. 2012;92:2020-8. https://doi.org/10.1002/jsfa.5712.

17. Bingham SA. Starch, nonstarch polysaccharides, and the large gut. In: Kritchevsky D, Bonfield C, Anderson JW, editors. Dietary fiber. Boston, MA: Springer US; 1990. p. 447-454. https:// doi.org/10.1007/978-1-4613-0519-4_33.

18. Fincher GB, Stone BA. CEREALS I Chemistry of nonstarch polysaccharides. In: Wrigley C, editor. Encyclopedia of grain science. Oxford: Elsevier; 2004. p. 206-223. https://doi.org/10. 1016/B0-12-765490-9/00107-5.

19. Williams BA, Mikkelsen D, Flanagan BM, et al. "Dietary fibre": moving beyond the "soluble/insoluble" classification for monogastric nutrition, with an emphasis on humans and pigs. J Anim Sci Biotechnol. 2019;10:45. https://doi.org/10.1186/ s40104-019-0350-9.

20. Zaman SA, Sarbini SR. The potential of resistant starch as a prebiotic. Crit Rev Biotechnol. 2016;36:578-84. https://doi. org/10.3109/07388551.2014.993590. 
21. Arena MP, Caggianiello G, Fiocco D, Russo P, Torelli M, Spano G, et al. Barley $\beta$-glucans-containing food enhances probiotic performances of beneficial bacteria. Int J Mol Sci. 2014;15:3025-39. https://doi.org/10.3390/ijms15023025.

22. O'Keefe SJ. The association between dietary fibre deficiency and high-income lifestyle-associated diseases: Burkitt's hypothesis revisited. Lancet Gastroenterol Hepatol. 2019;4:984-96. https:// doi.org/10.1016/S2468-1253(19)30257-2.

23. Ewaschuk JB, Dieleman LA. Probiotics and prebiotics in chronic inflammatory bowel diseases. World J Gastroenterol. 2006;12:5941-50. https://doi.org/10.3748/wjg.v12.i37.5941.

24. Looijer-van Langen MAC, Dieleman LA. Prebiotics in chronic intestinal inflammation. Inflamm Bowel Dis. 2009;15:454-62. https://doi.org/10.1002/ibd.20737.

25. Cristofori F, Dargenio VN, Dargenio C, Miniello VL, Barone M, Francavilla R. Anti-inflammatory and immunomodulatory effects of probiotics in gut inflammation: a door to the body. Front Immunol. 2021;12: 578386. https://doi.org/10.3389/ fimmu.2021.578386.

26. Ryan JJ, Monteagudo-Mera A, Contractor N, et al. Impact of 2 -fucosyllactose on gut microbiota composition in adults with chronic gastrointestinal conditions: batch culture fermentation model and pilot clinical trial findings. Nutrients. 2021. https:// doi.org/10.3390/nu13030938.

27. Sartor RB. Therapeutic manipulation of the enteric microflora in inflammatory bowel diseases: antibiotics, probiotics, and prebiotics. Gastroenterology. 2004;126:1620-33. https://doi.org/10. 1053/j.gastro.2004.03.024.

28. Cuello-Garcia C, Fiocchi A, Pawankar R, Yepes-Nuñez JJ, Morgano GP, Zhang Y, et al. Prebiotics for the prevention of allergies: a systematic review and meta-analysis of randomized controlled trials. Clin Exp Allergy. 2017;47:1468-77. https:// doi.org/10.1111/cea.13042.

29. Jesenak M, Banovcin P, Rennerova Z, Majtan J. $\beta$-Glucans in the treatment and prevention of allergic diseases. Allergol Immunopathol (Madr). 2014;42:149-56. https://doi.org/10.1016/j.aller. 2012.08.008.

30. Lee YH, Verma NK, Thanabalu T. Prebiotics in atopic dermatitis prevention and management. J Funct Foods. 2021;78:104352. https://doi.org/10.1016/j.jff.2021.104352.

31. West CE, Dzidic M, Prescott SL, et al. Bugging allergy; role of pre-, pro- and synbiotics in allergy prevention. Allergol Int. 2017;66:529-38. https://doi.org/10.1016/j.alit.2017.08.001.

32. Osborn DA, Sinn JKH. Prebiotics in infants for prevention of allergy. Cochrane Database Syst Rev. 2013:CD006474. https:// doi.org/10.1002/14651858.CD006474.pub3.

33. Bunyavanich S, Berin MC. Food allergy and the microbiome: current understandings and future directions. J Allergy Clin Immunol. 2019;144:1468-77. https://doi.org/10.1016/j.jaci. 2019.10.019.

34. Nance CL, Deniskin R, Diaz VC, Paul M, Anvari S, Anagnostou A. The role of the microbiome in food allergy: a review. Children (Basel). 2020. https://doi.org/10.3390/children7060050.

35. Kerperien J, Jeurink PV, Wehkamp T, van der Veer A, van de Kant HJG, Hofman GA, et al. Non-digestible oligosaccharides modulate intestinal immune activation and suppress cow's milk allergic symptoms. Pediatr Allergy Immunol. 2014;25:747-54. https://doi.org/10.1111/pai.12311.

36. Folkerts J, Stadhouders R, Redegeld FA, Tam S-Y, Hendriks RW, Galli SJ, et al. Effect of dietary fiber and metabolites on mast cell activation and mast cell-associated diseases. Front Immunol. 2018;9:1067. https://doi.org/10.3389/fimmu.2018.01067.

37. Pretorius R, Prescott SL, Palmer DJ. Taking a prebiotic approach to early immunomodulation for allergy prevention. Expert Rev Clin Immunol. 2018;14:43-51. https://doi.org/10. 1080/1744666X.2018.1411191.
38. Eiwegger T, Stahl B, Haidl P, Schmitt J, Boehm G, Dehlink E, et al. Prebiotic oligosaccharides: in vitro evidence for gastrointestinal epithelial transfer and immunomodulatory properties. Pediatr Allergy Immunol. 2010;21:1179-88. https://doi.org/10. 1111/j.1399-3038.2010.01062.x.

39. Zhang Z, Shi L, Pang W, Liu W, Li J, Wang H, et al. Dietary fiber intake regulates intestinal microflora and inhibits ovalbumininduced allergic airway inflammation in a mouse model. PLoS One. 2016;11: e0147778. https://doi.org/10.1371/journal.pone. 0147778 .

40. Chen J, Liang R, Liu W, Li T, Liu C, Wu S, et al. Pecticoligosaccharides prepared by dynamic high-pressure microfluidization and their in vitro fermentation properties. Carbohydr Polym. 2013;91:175-82. https://doi.org/10.1016/j.carbpol. 2012.08.021.

41. Mualikrishna G, Tharanathan RN. Characterization of pectic polysaccharides from pulse husks. Food Chem. 1994;50:87-9. https://doi.org/10.1016/0308-8146(94)90098-1.

42. Dongowski G, Whistler RL, BeMiller JN. Carbohydrate chemistry for food scientists. Nahrung. 1997;41:318. https://doi.org/10. 1002/food.19970410523.

43. Willats WG, Knox JP, Mikkelsen JD. Pectin: new insights into an old polymer are starting to gel. Trends Food Sci Technol. 2006;17:97-104. https://doi.org/10.1016/j.tifs.2005.10.008.

44. Liang R, Chen J, Liu W, Liu C, Yu W, Yuan M, et al. Extraction, characterization and spontaneous gel-forming property of pectin from creeping fig (Ficus pumila Linn.) seeds. Carbohydr Polym. 2012;87:76-83. https://doi.org/10.1016/j.carbpol.2011.07.013.

45. Ishii T. O-acetylated oligosaccharides from pectins of potato tuber cell walls. Plant Physiol. 1997;113:1265-72. https://doi. org/10.1104/pp.113.4.1265.

46. Alba K, Bingham RJ, Gunning PA, Wilde PJ, Kontogiorgos V. Pectin conformation in solution. J Phys Chem B. 2018;122:728694. https://doi.org/10.1021/acs.jpcb.8b04790.

47. Sila DN, van Buggenhout S, Duvetter T, Fraeye I, de Roeck A, van Loey A, et al. Pectins in processed fruits and vegetables: part IIstructure-function relationships. Comp Rev Food Sci Food Safety. 2009;8:86-104. https://doi.org/10.1111/j.1541-4337.2009.00071.x.

48. Vanitha T, Khan M. Role of pectin in food processing and food packaging. In: Masuelli MA, editor. Pectins: extraction, purification, characterization and applications. London: IntechOpen; 2020. https://doi.org/10.5772/intechopen.83677.

49. Tian L, Bruggeman G, van den Berg M, Borewicz K, Scheurink AJW, Bruininx E, et al. Effects of pectin on fermentation characteristics, carbohydrate utilization, and microbial community composition in the gastrointestinal tract of weaning pigs. Mol Nutr Food Res. 2017. https://doi.org/10.1002/mnfr.201600186.

50. Popov SV, Ovodov YS. Polypotency of the immunomodulatory effect of pectins. Biochemistry Mosc. 2013;78:823-35. https:// doi.org/10.1134/S0006297913070134.

51. Gullón B, Gómez B, Martínez-Sabajanes M, Yáñez R, Parajó JC, Alonso JL. Pectic oligosaccharides: manufacture and functional properties. Trends Food Sci Technol. 2013;30:153-61. https:// doi.org/10.1016/j.tifs.2013.01.006.

52. Babbar N, Dejonghe W, Sforza S, Elst K. Enzymatic pectic oligosaccharides (POS) production from sugar beet pulp using response surface methodology. J Food Sci Technol. 2017;54:3707-15. https://doi.org/10.1007/s13197-017-2835-x.

53. Kerperien J, Veening-Griffioen D, Wehkamp T, van Esch BCAM, Hofman GA, Cornelissen P, et al. IL-10 Receptor or TGF- $\beta$ Neutralization abrogates the protective effect of a specific nondigestible oligosaccharide mixture in cow-milk-allergic mice. J Nutr. 2018;148:1372-9. https://doi.org/10.1093/jn/nxy104.

54. Kostadinova AI, Pablos-Tanarro A, Diks MAP, van Esch BCAM, Garssen J, Knippels LMJ, et al. Dietary intervention with $\beta$-lactoglobulin-derived peptides and a specific mixture 
of fructo-oligosaccharides and Bifidobacterium breve M-16V facilitates the prevention of whey-induced allergy in mice by supporting a tolerance-prone immune environment. Front Immunol. 2017;8:1303. https://doi.org/10.3389/fimmu.2017.01303.

55. Grüber C, van Stuijvenberg M, Mosca F, Moro G, Chirico G, Braegger CP, et al. Reduced occurrence of early atopic dermatitis because of immunoactive prebiotics among low-atopy-risk infants. J Allergy Clin Immunol. 2010;126:791-7. https://doi. org/10.1016/j.jaci.2010.07.022.

56. Vos AP, van Esch BC, Stahl B, M'Rabet L, Folkerts G, Nijkamp FP, et al. Dietary supplementation with specific oligosaccharide mixtures decreases parameters of allergic asthma in mice. Int Immunopharmacol. 2007;7:1582-7. https://doi.org/10.1016/j. intimp.2007.07.024.

57. Burkitt DP, Walker AR, Painter NS. Effect of dietary fibre on stools and the transit-times, and its role in the causation of disease. Lancet. 1972;2:1408-12. https://doi.org/10.1016/s01406736(72)92974-1.

58. Cummings JH. Dietary fibre Gut. 1973;14:69-81. https://doi.org/ 10.1136/gut.14.1.69.

59. Flourie B, Vidon N, Florent CH, Bernier JJ. Effect of pectin on jejunal glucose absorption and unstirred layer thickness in normal man. Gut. 1984;25:936-41. https://doi.org/10.1136/gut. 25.9.936.

60. Schwartz SE, Levine RA, Singh A, Scheidecker JR, Track NS. Sustained pectin ingestion delays gastric emptying. Gastroenterology. 1982;83:812-7.

61. Hotchkiss AT, Olano-Martin E, Grace WE, Gibson GR, Rastall RA. Pectic oligosaccharides as prebiotics. In: Eggleston G, Côté GL, editors. Oligosaccharides in food and agriculture. Washington, DC: American Chemical Society; 2003. p. 54-62. https:// doi.org/10.1021/bk-2003-0849.ch005.

62. Thakur BR, Singh RK, Handa AK. Chemistry and uses of pectin-a review. Crit Rev Food Sci Nutr. 1997;37:47-73. https:// doi.org/10.1080/10408399709527767.

63. Moon JS, Shin SY, Choi HS, Joo W, Cho SK, Li L, et al. In vitro digestion and fermentation properties of linear sugar-beet arabinan and its oligosaccharides. Carbohydr Polym. 2015;131:506. https://doi.org/10.1016/j.carbpol.2015.05.022.

64. Islamova ZhI, Ogai DK, Abramenko OI, Lim AL, Abduazimov $\mathrm{BB}$, Malikova MKh, et al. Comparative assessment of the prebiotic activity of some pectin polysaccharides. Pharm Chem J. 2017;51:288-91. https://doi.org/10.1007/s11094-017-1600-9.

65. Shtriker MG, Hahn M, Taieb E, Nyska A, Moallem U, Tirosh $\mathrm{O}$, et al. Fenugreek galactomannan and citrus pectin improve several parameters associated with glucose metabolism and modulate gut microbiota in mice. Nutrition. 2018;46:134-142. e3. https://doi.org/10.1016/j.nut.2017.07.012.

66. Chung WSF, Meijerink M, Zeuner B, Holck J, Louis P, Meyer AS, et al. Prebiotic potential of pectin and pectic oligosaccharides to promote anti-inflammatory commensal bacteria in the human colon. FEMS Microbiol Ecol. 2017. https://doi.org/10. $1093 /$ femsec/fix 127. Shows that pectin supplementation is able to modify the gut microbiota. Changes in $\mathrm{pH}$ can as well modify the microbiota balance.

67. Salyers AA, Vercellotti JR, West SE, et al. Fermentation of mucin and plant polysaccharides by strains of Bacteroides from the human colon. Appl Environ Microbiol. 1977;33:319-22.

68. Chung WSF, Walker AW, Louis P, Parkhill J, Vermeiren J, Bosscher $\mathrm{D}$, et al. Modulation of the human gut microbiota by dietary fibres occurs at the species level. BMC Biol. 2016;14:3. https://doi.org/ 10.1186/s12915-015-0224-3.

69. Gómez B, Gullón B, Remoroza C, Schols HA, Parajó JC, Alonso JL. Purification, characterization, and prebiotic properties of pectic oligosaccharides from orange peel wastes. J Agric Food Chem. 2014;62:9769-82. https://doi.org/10.1021/jf503475b.
70. Blaut M. Relationship of prebiotics and food to intestinal microflora. Eur J Nutr. 2002;41(Suppl 1):I11-6. https://doi.org/10. 1007/s00394-002-1102-7.

71. Li X, Shimizu Y, Kimura I. Gut microbial metabolite shortchain fatty acids and obesity. Biosci Microbiota Food Health. 2017;36:135-40. https://doi.org/10.12938/bmfh.17-010.

72. Bartolomaeus H, Balogh A, Yakoub M, Homann S, Markó L, Höges S, et al. Short-chain fatty acid propionate protects from hypertensive cardiovascular damage. Circulation. 2019;139:140721. https://doi.org/10.1161/CIRCULATIONAHA.118.036652.

73. Ohira H, Tsutsui W, Fujioka Y. Are short chain fatty acids in gut microbiota defensive players for inflammation and atherosclerosis? J Atheroscler Thromb. 2017;24:660-72. https://doi.org/10. 5551/jat.RV17006.

74. Parada Venegas D, De la Fuente MK, Landskron G, González MJ, Quera R, et al. Short chain fatty acids (SCFAs)-mediatedgut epithelial and immune regulation and its relevance for inflammatory bowel diseases. Front Immunol 2019;10:277. https://doi. org/10.3389/fimmu.2019.00277

75. Srivastava P, Malviya R. Sources of pectin, extraction and its applications in pharmaceutical industry - An overview. Indian J Nat Prod Resour. 2011;2:10-18.

76. Anderson JW, Lin Chen W-J, Sieling B. Hypolipidemic effects of high-carbohydrate, high-fiber diets. Metabolism. 1980;29:551-8. https://doi.org/10.1016/0026-0495(80)90081-5.

77. Madar Z. Effect of brown rice and soybean dietary fiber on the control of glucose and lipid metabolism in diabetic rats. Am J Clin Nutr. 1983;38:388-93. https://doi.org/10.1093/ajcn/38.3.388.

78. Chang JH, Kim MS, Kim TW, et al. Effects of soybean supplementation on blood glucose, plasma lipid levels, and erythrocyte antioxidant enzyme activity in type 2 diabetes mellitus patients. Nutr Res Pract. 2008;2:152-7. https://doi.org/10.4162/nrp.2008.2.3.152.

79. Brouns F, Theuwissen E, Adam A, Bell M, Berger A, Mensink RP. Cholesterol-lowering properties of different pectin types in mildly hyper-cholesterolemic men and women. Eur J Clin Nutr. 2012;66:591-9. https://doi.org/10.1038/ejen.2011.208.

80. EFSA Panel on Dietetic Products, Nutrition and Allergies. Scientific Opinion on the substantiation of health claims related to protein and increase in satiety leading to a reduction in energy intake (ID 414,616,730), contribution to the maintenance or achievement of a normal body weight (ID 414, 616, 730), maintenance of normal bone (ID 416) and growth or maintenance of muscle mass (ID 415, 417, 593, 594, 595, 715) pursuant to Article 13(1) of Regulation (EC) No 1924/2006. EFSA Journal. 2010;8:1811. https://doi.org/10.2903/j.efsa.2010.1811.

81. Sriamornsak P. Chemistry of pectin and its pharmaceutical uses: a review. Silpakorn University International Journal. 2003;3:206-228

82. Elamin EE, Masclee AA, Dekker J, Pieters H-J, et al. Short-chain fatty acids activate AMP-activated protein kinase and ameliorate ethanol-induced intestinal barrier dysfunction in Caco- 2 cell monolayers. J Nutr. 2013;143:1872-81. https://doi.org/10.3945/ jn.113.179549.

83. He J, Zhang P, Shen L, Niu L, Tan Y, Chen L, et al. Shortchain fatty acids and their association with signalling pathways in inflammation, glucose and lipid metabolism. Int J Mol Sci. 2020. https://doi.org/10.3390/ijms21176356.

84. den Besten G, van Eunen K, Groen AK, Venema K, Reijngoud D-J, Bakker BM. The role of short-chain fatty acids in the interplay between diet, gut microbiota, and host energy metabolism. J Lipid Res. 2013;54:2325-40. https://doi.org/10.1194/jlr.R036012.

85. Chen Y, Xu C, Huang R, Song J, Di Li, Xia M. Butyrate from pectin fermentation inhibits intestinal cholesterol absorption and attenuates atherosclerosis in apolipoprotein E-deficient mice. J Nutr Biochem. 2018;56:175-182. https://doi.org/10. 1016/j.jnutbio.2018.02.011. 
86. Xie J, Yu R, Qi J, Zhang G, Peng X, Luo J. Pectin and inulin stimulated the mucus formation at a similar level: an omicsbased comparative analysis. J Food Sci. 2020. https://doi.org/ 10.1111/1750-3841.15163.

87. Wu C, Pan L-L, Niu W, Fang X, Liang W, Li J, et al. Modulation of gut microbiota by low methoxyl pectin attenuates type 1 diabetes in non-obese diabetic mice. Front Immunol. 2019;10:1733. https://doi.org/10.3389/fimmu.2019.01733.

88. García-Carrizo F, Picó C, Rodríguez AM, et al. High-esterified pectin reverses metabolic malprogramming, improving sensitivity to adipostatic/adipokine hormones. J Agric Food Chem. 2019;67:3633-42. https://doi.org/10.1021/acs.jafc.9b00296.

89. Sun Y, He Y, Wang F, Zhang H, de Vos P, Sun J. Low-methoxyl lemon pectin attenuates inflammatory responses and improves intestinal barrier integrity in caerulein-induced experimental acute pancreatitis. Mol Nutr Food Res. 2017. https://doi.org/10.1002/ mnfr.201600885.

90. McIntosh M, Miller C. A diet containing food rich in soluble and insoluble fiber improves glycemic control and reduces hyperlipidemia among patients with type 2 diabetes mellitus. Nutr Rev. 2001;59:525. https://doi.org/10.1111/j.1753-4887.2001.tb06976.x.

91. Rowland IR, Mallett AK, Flynn J, et al. The effect of various dietary fibres on tissue concentration and chemical form of mercury after methylmercury exposure in mice. Arch Toxicol. 1986;59:94-8. https://doi.org/10.1007/BF00286730.

92. Waldron-Edward D, Paul TM, Skoryna SC. Suppression of intestinal absorption of radioactive strontium by naturally occurring non-absorbable polyelectrolytes. Nature. 1965;205:1117-8. https://doi.org/10.1038/2051117a0.

93. Paskins-Hurlburt AJ, Tanaka Y, Skoryna SC, et al. The binding of lead by a pectic polyelectrolyte. Environ Res. 1977;14:128-40. https://doi.org/10.1016/0013-9351(77)90074-3.

94. Platt D, Raz A. Modulation of the lung colonization of B16-F1 melanoma cells by citrus pectin. J Natl Cancer Inst. 1992;84:438-42. https://doi.org/10.1093/jnci/84.6.438.

95. Inohara H, Raz A. Effects of natural complex carbohydrate (citrus pectin) on murine melanoma cell properties related to galectin-3 functions. Glycoconj J. 1994;11:527-32. https://doi. org/10.1007/BF00731303.

96. Li Y, Niu Y, Wu H, Sun Y, Li Q, Kong X, et al. Modified apple polysaccharides could induce apoptosis in colorectal cancer cells. J Food Sci. 2010;75:H224-9. https://doi.org/10.1111/j. 1750-3841.2010.01781.x.

97. Zeng H, Li P, Zhou L, et al. A novel pectin from Polygala tenuifolia blocks $\mathrm{A} \beta 42$ aggregation and production by enhancing insulin-degradation enzyme and neprilysin. Int J Biol Macromol. 2020. https://doi.org/10.1016/j.ijbiomac.2020.05.212.

98.• Trompette A, Gollwitzer ES, Yadava K, Sichelstiel AK, Sprenger N, Ngom-Bru C, et al. Gut microbiota metabolism of dietary fiber influences allergic airway disease and hematopoiesis. Nat Med. 2014;20:159-66. https://doi.org/10.1038/ $\mathrm{nm} .3444$. This study showed in a murine model that high consumption of pectin increased the SCFA concentration and the protection against lung inflammation.

99. Gibson GR, Probert HM, van Loo J, et al. Dietary modulation of the human colonic microbiota: updating the concept of prebiotics. Nutr Res Rev. 2004;17:259-75. https://doi.org/10. 1079/NRR200479.

100. Larsen N, Bussolo de Souza C, Krych L, Barbosa Cahú T, Wiese $\mathrm{M}$, Kot W, et al. Potential of pectins to beneficially modulate the gut microbiota depends on their structural properties. Front Microbiol. 2019;10:223. https://doi.org/10.3389/fmicb.2019. 00223. The study links the structural features of pectin and the survival of probiotics through the intestinal tract.

101. Prado SBR, Beukema M, Jermendi E, Schols HA, de Vos P, Fabi JP. Pectin interaction with immune receptors is modulated by ripening process in papayas. Sci Rep. 2020;10:1690. https:// doi.org/10.1038/s41598-020-58311-0.

102. Minzanova ST, Mironov VF, Arkhipova DM, Khabibullina AV, Mironova LG, Zakirova YM, et al. Biological activity and pharmacological application of pectic polysaccharides: a review. Polymers (Basel). 2018. https://doi.org/10.3390/ polym10121407.

103. Beukema M, Faas MM, de Vos P. The effects of different dietary fiber pectin structures on the gastrointestinal immune barrier: impact via gut microbiota and direct effects on immune cells. Exp Mol Med. 2020;52:1364-76. https://doi.org/10.1038/s12276-020-0449-2.

104. Vogt L, Ramasamy U, Meyer D, Pullens G, Venema K, Faas $\mathrm{MM}$, et al. Immune modulation by different types of $\beta 2 \rightarrow 1$ fructans is toll-like receptor dependent. PLoS One. 2013;8: e68367. https://doi.org/10.1371/journal.pone.0068367.

105. Sahasrabudhe NM, Beukema M, Tian L, Troost B, Scholte J, Bruininx E, et al. Dietary fiber pectin directly blocks toll-like receptor $2-1$ and prevents doxorubicin-induced ileitis. Front Immunol. 2018;9:383. https://doi.org/10.3389/fimmu.2018. 00383.

106. Chen C-H, Sheu M-T, Chen T-F, Wang Y-C, Hou W-C, Liu $\mathrm{D}-\mathrm{Z}$, et al. Suppression of endotoxin-induced proinflammatory responses by citrus pectin through blocking LPS signaling pathways. Biochem Pharmacol. 2006;72:1001-9. https://doi.org/10. 1016/j.bcp.2006.07.001.

107. Ramachandran C, Wilk BJ, Hotchkiss A, Chau H, Eliaz I, Melnick SJ. Activation of human T-helper/inducer cell, T-cytotoxic cell, B-cell, and natural killer (NK)-cells and induction of natural killer cell activity against K562 chronic myeloid leukemia cells with modified citrus pectin. BMC Complement Altern Med. 2011;11:59. https://doi.org/ 10.1186/1472-6882-11-59.

108. Merheb R, Abdel-Massih RM, Karam MC. Immunomodulatory effect of natural and modified Citrus pectin on cytokine levels in the spleen of BALB/c mice. Int J Biol Macromol. 2019;121:1-5. https://doi.org/10.1016/j.ijbiomac.2018.09.189.

109. Liu L, Fishman ML, Hicks KB, et al. Interaction of various pectin formulations with porcine colonic tissues. Biomaterials. 2005;26:5907-16. https://doi.org/10.1016/j.biomaterials.2005. 03.005 .

110. Ferdman RM, Ong PY, Church JA. Pectin anaphylaxis and possible association with cashew allergy. Ann Allergy Asthma Immunol. 2006;97:759-60. https://doi.org/10.1016/S1081-1206(10) 60966-0.

111. Capucilli P, Kennedy K, Kazatsky AM, et al. Fruit for thought: anaphylaxis to fruit pectin in foods. J Allergy Clin Immunol Pract. 2019;7:719-20. https://doi.org/10.1016/j.jaip.2018.11. 047.

112. Iwamoto $\mathrm{A}$, Inoue $\mathrm{Y}$, Tachibana $\mathrm{H}$, et al. Alkali-soluble pectin suppresses IgE production in human myeloma cell line in vitro. Cytotechnology. 2019;71:573-81. https://doi.org/10.1007/ s10616-019-00306-5.

113. Uno H, Sekimoto H, Kitamura T. A case of a 7-year-old girl with anaphylaxis caused by pectin in Albedo of Citrus Unshiu but not by the fruit itself. Arerugi. 2017;66:1244-7. https:// doi.org/10.15036/arerugi.66.1244.

114. Räsänen L, Mäkinen-Kiljunen S, Harvima RJ. Pectin and cashew nut allergy: cross-reacting allergens? Allergy. 1998;53:626-8. https://doi.org/10.1111/j.1398-9995.1998.tb03946.x.

115. Polovic N, Blanusa M, Gavrovic-Jankulovic M, AtanaskovicMarkovic M, Burazer L, Jankov R, et al. A matrix effect in pectin-rich fruits hampers digestion of allergen by pepsin in vivo and in vitro. Clin Exp Allergy. 2007;37:764-71. https://doi.org/ 10.1111/j.1365-2222.2007.02703.x.

116. Peyron S, Mouécoucou J, Frémont $S$, et al. Effects of heat treatment and pectin addition on beta-lactoglobulin allergenicity. $\mathrm{J}$ 
Agric Food Chem. 2006;54:5643-50. https://doi.org/10.1021/ jf053178j.

117. Kraut A, Peng Z, Becker AB, et al. Christmas candy maker's asthma. IgG4-mediated pectin allergy. Chest. 1992;102:160507. https://doi.org/10.1378/chest.102.5.1605.

118. Cohen AJ, Forse MS, Tarlo SM. Occupational asthma caused by pectin inhalation during the manufacture of jam. Chest. 1993;103:309-11. https://doi.org/10.1378/chest.103.1.309.

119. Jaakkola MS, Tammivaara R, Tuppurainen M, Lahdenne L, Tupasela O, Keskinen H. Asthma caused by occupational expo-

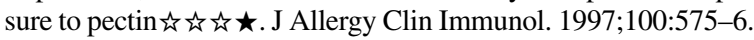
https://doi.org/10.1016/S0091-6749(97)70153-2.

120. Khramova DS, Popov SV, Golovchenko VV, Vityazev FV, Paderin NM, Ovodov YS. Abrogation of the oral tolerance to ovalbumin in mice by citrus pectin. Nutrition. 2009;25:226-32. https://doi.org/ 10.1016/j.nut.2008.08.004

121. Tan J, McKenzie C, Potamitis M, Thorburn AN, Mackay CR, Macia L. The role of short-chain fatty acids in health and disease. Adv Immunol. 2014;121:91-119. https://doi.org/10.1016/ B978-0-12-800100-4.00003-9.

122. Lee JC, Pak SC, Lee SH, Na CS, Lim SC, Song CH, et al. Asian pear pectin administration during presensitization inhibits allergic response to ovalbumin in BALB/c mice. J Altern Complement Med. 2004;10:527-34. https://doi.org/10.1089/ 1075553041323867.

123. Marounek M, Duskova D. Metabolism of pectin in rumen bacteria Butyrivibrio fibrisolvens and Prevotella ruminicola. Lett Appl Microbiol. 1999;29:429-33. https://doi.org/10.1046/j. 1472-765X.1999.00671.x

124. Duncan SH, Holtrop G, Lobley GE, Calder AG, Stewart CS, Flint HJ. Contribution of acetate to butyrate formation by human faecal bacteria. Br J Nutr. 2004;91:915-23. https://doi.org/10. 1079/BJN20041150.

125. Nakajima N, Ishihara K, Matsuura Y. Dietary-fiber-degrading enzymes from a human intestinal Clostridium and their application to oligosaccharide production from nonstarchy polysaccharides using immobilized cells. Appl Microbiol Biotechnol. 2002;59:182-9. https://doi.org/10.1007/s00253-002-1015-7.

126. Matsuura Y. Pectic acid degrading enzymes from human feces. Agric Biol Chem. 1991;55:885-6. https://doi.org/10.1271/bbb1961.55.885.

127. Grondin JM, Tamura K, Déjean G, et al. Polysaccharide utilization loci: fueling microbial communities. J Bacteriol. 2017. https://doi.org/10.1128/JB.00860-16.

128. Onumpai C, Kolida S, Bonnin E, et al. Microbial utilization and selectivity of pectin fractions with various structures. Appl Environ Microbiol. 2011;77:5747-54. https://doi.org/10.1128/ AEM.00179-11.

129. Manderson K, Pinart M, Tuohy KM, Grace WE, Hotchkiss AT, Widmer $\mathrm{W}$, et al. In vitro determination of prebiotic properties of oligosaccharides derived from an orange juice manufacturing by-product stream. Appl Environ Microbiol. 2005;71:8383-9. https://doi.org/10.1128/AEM.71.12.8383-8389.2005.

130. Leijdekkers AGM, Aguirre M, Venema K, Bosch G, Gruppen $\mathrm{H}$, Schols HA. In vitro fermentability of sugar beet pulp derived oligosaccharides using human and pig fecal inocula. J Agric Food Chem. 2014;62:1079-87. https://doi.org/10.1021/jf4049676.

131. Aguirre M, Jonkers DMAE, Troost FJ, et al. In vitro characterization of the impact of different substrates on metabolite production, energy extraction and composition of gut microbiota from lean and obese subjects. PLoS One. 2014;9: e113864. https:// doi.org/10.1371/journal.pone.0113864.

132. Jiang T, Gao X, Wu C, Tian F, Lei Q, Bi J, et al. Applederived pectin modulates gut microbiota, improves gut barrier function, and attenuates metabolic endotoxemia in rats with diet-induced obesity. Nutrients. 2016;8:126. https://doi.org/ 10.3390/nu8030126.
133. $\bullet$ Tingirikari JMR. Microbiota-accessible pectic poly- and oligosaccharides in gut health. Food Funct. 2018;9:5059-73. https://doi.org/10.1039/c8fo01296b. Not only pectin, but POS are able to promote the growth of beneficial microbiota such as Bifidobacteria and Bacteriodes as well as increased the SCFA production.

134. Adam CL, Gratz SW, Peinado DI, Thomson LM, Garden KE, Williams PA, et al. Effects of dietary fibre (pectin) and/or increased protein (casein or pea) on satiety, body weight, adiposity and caecal fermentation in high fat diet-induced obese rats. PLoS One. 2016;11: e0155871. https://doi.org/10.1371/journal. pone.0155871.

135. van Laere KM, Hartemink R, Bosveld M, et al. Fermentation of plant cell wall derived polysaccharides and their corresponding oligosaccharides by intestinal bacteria. J Agric Food Chem. 2000;48:1644-52. https://doi.org/10.1021/jf990519i.

136. Gómez B, Gullón B, Yáñez R, et al. Prebiotic potential of pectins and pectic oligosaccharides derived from lemon peel wastes and sugar beet pulp: a comparative evaluation. J Funct Foods. 2016;20:108-21. https://doi.org/10.1016/j.jff.2015.10.029.

137. Li P, Xia J, Nie Z, et al. Pectic oligosaccharides hydrolyzed from orange peel by fungal multi-enzyme complexes and their prebiotic and antibacterial potentials. LWT Food Sci Technol. 2016;69:203-10. https://doi.org/10.1016/j.lwt.2016.01.042.

138. Dongowski G, Lorenz A, Proll J. The degree of methylation influences the degradation of pectin in the intestinal tract of rats and in vitro. J Nutr. 2002;132:1935-44. https://doi.org/10.1093/ jn/132.7.1935.

139. Magne F, Hachelaf W, Suau A, Boudraa G, Bouziane-Nedjadi K, Rigottier-Gois L, et al. Effects on faecal microbiota of dietary and acidic oligosaccharides in children during partial formula feeding. J Pediatr Gastroenterol Nutr. 2008;46:580-8. https:// doi.org/10.1097/MPG.0b013e318164d920.

140. Ríos-Covián D, Ruas-Madiedo P, Margolles A, et al. Intestinal short chain fatty acids and their link with diet and human health. Front Microbiol 2016;7:185. https://doi.org/10.3389/fmicb.2016.00185

141. Bishehsari F, Engen PA, Preite NZ, Tuncil YE, Naqib A, Shaikh M, et al. Dietary fiber treatment corrects the composition of gut microbiota, promotes SCFA production, and suppresses colon carcinogenesis. Genes (Basel). 2018. https://doi. org/10.3390/genes9020102.

142. van der Beek CM, Dejong CHC, Troost FJ, Masclee AAM, Lenaerts $\mathrm{K}$. Role of short-chain fatty acids in colonic inflammation, carcinogenesis, and mucosal protection and healing. Nutr Rev. 2017;75:286305. https://doi.org/10.1093/nutrit/nuw067.

143. Fitzgibbon G, Mills KHG. The microbiota and immune-mediated diseases: Opportunities for therapeutic intervention. Eur J Immunol. 2020;50:326-37. https://doi.org/10.1002/eji.201948322. Reviews how gut microbiota modulates immune responses associated to human diseases.

144. Gulfi M, Arrigoni E, Amadò R. Influence of structure on in vitro fermentability of commercial pectins and partially hydrolysed pectin preparations. Carbohydr Polym. 2005;59:247-55. https:// doi.org/10.1016/j.carbpol.2004.09.018.

145. Chen T, Long W, Zhang C, Liu S, Zhao L, Hamaker BR. Fiberutilizing capacity varies in Prevotella- versus Bacteroides-dominated gut microbiota. Sci Rep. 2017;7:2594. https://doi.org/10.1038/ s41598-017-02995-4.

146. Reichardt N, Duncan SH, Young P, Belenguer A, McWilliam Leitch C, Scott KP, et al. Phylogenetic distribution of three pathways for propionate production within the human gut microbiota. ISME J. 2014;8:1323-35. https://doi.org/10.1038/ismej.2014.14.

147. Qin J, Li R, Raes J, Arumugam M, Burgdorf KS, Manichanh $\mathrm{C}$, et al. A human gut microbial gene catalogue established by metagenomic sequencing. Nature. 2010;464:59-65. https://doi. org/10.1038/nature08821. 
148. Thorburn AN, McKenzie CI, Shen S, Stanley D, Macia L, Mason $\mathrm{LJ}$, et al. Evidence that asthma is a developmental origin disease influenced by maternal diet and bacterial metabolites. Nat Commun. 2015;6:7320. https://doi.org/10.1038/ncomms8320.

149. Bourquin LD, Titgemeyer EC, Fahey GC. Fermentation of various dietary fiber sources by human fecal bacteria. Nutr Res. 1996;16:1119-31. https://doi.org/10.1016/0271-5317(96)00116-9.

150. Louis P, Flint HJ. Formation of propionate and butyrate by the human colonic microbiota. Environ Microbiol. 2017;19:29-41. https://doi.org/10.1111/1462-2920.13589.

151. Hirata S-I, Kunisawa J. Gut microbiome, metabolome, and allergic diseases. Allergol Int. 2017;66:523-8. https://doi.org/ 10.1016/j.alit.2017.06.008.

152. Pryde SE, Duncan SH, Hold GL, et al. The microbiology of butyrate formation in the human colon. FEMS Microbiol Lett. 2002;217:1339. https://doi.org/10.1111/j.1574-6968.2002.tb11467.x.

153. Kim CH, Park J, Kim M. Gut microbiota-derived shortchain fatty acids, $\mathrm{T}$ cells, and inflammation. Immune Netw. 2014;14:277-88. https://doi.org/10.4110/in.2014.14.6.277.

154. Luu M, Monning H, Visekruna A. Exploring the molecular mechanisms underlying the protective effects of microbial SCFAs on intestinal tolerance and food allergy. Front Immunol. 2020;11:1225. https://doi.org/10.3389/fimmu.2020.01225.

155. Mao G, Li S, Orfila C, Shen X, Zhou S, Linhardt RJ, et al. Depolymerized RG-I-enriched pectin from citrus segment membranes modulates gut microbiota, increases SCFA production, and promotes the growth of Bifidobacterium spp., Lactobacillus spp. and Faecalibaculum spp. Food Funct. 2019;10:7828-43. https:// doi.org/10.1039/c9fo01534e.

156. Tian L, Scholte J, Borewicz K, van den Bogert B, Smidt H, Scheurink AJW, et al. Effects of pectin supplementation on the fermentation patterns of different structural carbohydrates in rats. Mol Nutr Food Res. 2016;60:2256-66. https://doi.org/10. 1002/mnfr.201600149.

157. Macfarlane GT, Macfarlane S. Bacteria, colonic fermentation, and gastrointestinal health. J AOAC Int. 2012;95:50-60. https:// doi.org/10.5740/jaoacint.sge_macfarlane.

158. Smith PM, Howitt MR, Panikov N, Michaud M, Gallini CA, Bohlooly-Y M, et al. The microbial metabolites, short-chain fatty acids, regulate colonic Treg cell homeostasis. Science. 2013;341:569-73. https://doi.org/10.1126/science.1241165.

159. Canani RB, Di Costanzo M, Leone L, Pedata M, Meli R, Calignano A. Potential beneficial effects of butyrate in intestinal and extraintestinal diseases. World J Gastroenterol. 2011;17:1519-28. https://doi.org/10.3748/wjg.v17.i12.1519.

160. Macia L, Mackay CR. Dysfunctional microbiota with reduced capacity to produce butyrate as a basis for allergic diseases. $\mathrm{J}$ Allergy Clin Immunol. 2019;144:1513-5. https://doi.org/10. 1016/j.jaci.2019.10.009.

161.• Watt R, Parkin K, Martino D. The potential effects of short-chain fatty acids on the epigenetic regulation of innate immune memory. Challenges. 2020;11:25. https://doi.org/10.3390/challe11020025. Reviews the effects of gut microbiota, SCFAs, and epigenetic regulation of innate immunity.

162. Zhang Z, Tang H, Chen P, et al. Demystifying the manipulation of host immunity, metabolism, and extraintestinal tumors by the gut microbiome. Sig Transduct Target Ther. 2019. https://doi.org/10.1038/s41392-019-0074-5.

163. McKenzie C, Tan J, Macia L, et al. The nutrition-gut microbiome-physiology axis and allergic diseases. Immunol Rev. 2017;278:277-95. https://doi.org/10.1111/imr.12556.

164. Kim CH. Immune regulation by microbiome metabolites Immunology. 2018;154:220-9. https://doi.org/10.1111/imm.12930.

165. Halnes I, Baines KJ, Berthon BS, MacDonald-Wicks LK, Gibson PG, Wood LG. Soluble fibre meal challenge reduces airway inflammation and expression of GPR43 and GPR41 in asthma. Nutrients. 2017. https://doi.org/10.3390/nu9010057.

166. Tang H, Lu JY-L, Zheng X, et al. The psoriasis drug monomethylfumarate is a potent nicotinic acid receptor agonist. Biochem Biophys Res Commun. 2008;375:562-5. https://doi.org/10. 1016/j.bbrc.2008.08.041

167. Cresci GA, Thangaraju M, Mellinger JD, et al. Colonic gene expression in conventional and germ-free mice with a focus on the butyrate receptor GPR109A and the butyrate transporter SLC5A8. J Gastrointest Surg. 2010;14:449-61. https://doi.org/ 10.1007/s11605-009-1045-x.

168. Schaub A, Fütterer A, Pfeffer K, et al. an IFN- $\gamma$-inducible gene in macrophages is a novel member of the seven transmembrane spanning receptor superfamily. Eur J Immunol. 2001;31:371425. https://doi.org/10.1002/1521-4141(200112)31:12\%3c3714:: aid-immu3714\%3e3.0.co;2-1.

169. Benyó Z, Gille A, Bennett CL, et al, Offermanns S. Nicotinic acid-induced flushing is mediated by activation of epidermal langerhans cells. Mol Pharmacol. 2006;70:1844-9. https://doi. org/10.1124/mol.106.030833.

170. Thangaraju M, Cresci GA, Liu K, Ananth S, Gnanaprakasam JP, Browning DD, et al. GPR109A is a G-protein-coupled receptor for the bacterial fermentation product butyrate and functions as a tumor suppressor in colon. Cancer Res. 2009;69:2826-32. https://doi.org/10.1158/0008-5472.CAN-08-4466.

171. Digby JE, McNeill E, Dyar OJ, Lam V, Greaves DR, Choudhury RP. Anti-inflammatory effects of nicotinic acid in adipocytes demonstrated by suppression of fractalkine, RANTES, and MCP-1 and upregulation of adiponectin. Atherosclerosis. 2010;209:89-95. https://doi.org/10.1016/j.atherosclerosis.2009.08.045.

172. Chai JT, Digby JE, Choudhury RP. GPR109A and vascular inflammation. Curr Atheroscler Rep. 2013;15:325. https://doi. org/10.1007/s11883-013-0325-9.

173. Lukasova M, Malaval C, Gille A, et al. Nicotinic acid inhibits progression of atherosclerosis in mice through its receptor GPR109A expressed by immune cells. J Clin Invest. 2011;121:1163-73. https://doi.org/10.1172/JCI41651.

174. Gambhir D, Ananth S, Veeranan-Karmegam R, Elangovan S, Hester S, Jennings E, et al. GPR109A as an anti-inflammatory receptor in retinal pigment epithelial cells and its relevance to diabetic retinopathy. Invest Ophthalmol Vis Sci. 2012;53:220817. https://doi.org/10.1167/iovs.11-8447.

175. $\bullet$ Roduit C, Frei R, Ferstl R, Loeliger S, Westermann P, Rhyner $\mathrm{C}$, et al. High levels of butyrate and propionate in early life are associated with protection against atopy. Allergy. 2019;74:799809. https://doi.org/10.1111/all.13660. Shows the association between high levels of butyrate and propionate with the prevention of allergic diseases in the early life.

176. Li W, Zhang K, Yang H. Pectin alleviates high fat (lard) dietinduced nonalcoholic fatty liver disease in mice: possible role of short-chain fatty acids and gut microbiota regulated by pectin. J Agric Food Chem. 2018;66:8015-25. https://doi.org/10.1021/ acs.jafc.8b02979.

177. Fukunaga T, Sasaki M, Araki Y, Okamoto T, Yasuoka T, Tsujikawa T, et al. Effects of the soluble fibre pectin on intestinal cell proliferation, fecal short chain fatty acid production and microbial population. Digestion. 2003;67:42-9. https://doi.org/10.1159/000069705.

178. Bang S-J, Kim G, Lim MY, Song E-J, Jung D-H, Kum J-S, et al. The influence of in vitro pectin fermentation on the human fecal microbiome. AMB Express. 2018;8:98. https://doi.org/10.1186/ s13568-018-0629-9.

Publisher's Note Springer Nature remains neutral with regard to jurisdictional claims in published maps and institutional affiliations. 